\title{
EARTH, WIND, AND FIRE: Power Infrastructure in Alberta’s NeW Age
}

\author{
Cameron Hughes, Caitlin Graham, Charles July, \\ ADAM BROWN, THOMAS SCHUBERT, AND EMMA HAND*
}

\begin{abstract}
In the wake of dramatic policy changes commencing in late 2015, including the Government of Alberta's announcement of the Climate Leadership Plan, the Renewable Energy Program, and the decision to introduce a parallel capacity market into Alberta's previous energy-only market, the future of Alberta's electricity market is uncertain. However, regulatory intervention in an attempt to improve the function of electricity markets and encourage renewable generation is not a new concept.
\end{abstract}

Other jurisdictions, including the United Kingdom, Germany, and jurisdictions in the United States, have used regulatory intervention to address issues in energy markets and to drive renewable generation. Regulatory intervention in these jurisdictions has not always achieved the intended consequences. In some cases, regulatory intervention has exacerbated issues it intended to solve, or created new problems. In other cases, regulatory intervention has relatively improved the function of electricity markets and incited renewable generation. This paper considers the evolution of energy policy and competing policy drivers, including system reliability, use of sustainable fuels to generate electricity, and price surges. The paper will discuss the success and failure of regulatory intervention in select jurisdictions, and how these lessons might apply in the new age of Alberta's electricity market.

\section{TABLE OF CONTENTS}

I. INTRODUCTION . . . . . . . . . . . . . . . . . . . . . . . . . . . . . . . . . . . 440

II. Global TRENDS $\ldots \ldots \ldots \ldots \ldots \ldots \ldots \ldots \ldots \ldots \ldots \ldots \ldots . \ldots \ldots$

III. Alberta: Background And ReCEnt Policy Developments . . . . . . 443

A. THE FIRST 20 YEARS OF ALBERTA's

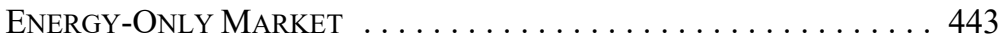

B. The Climate LEADERSHIP Plan

Challenges the Energy-Only Market . . . . . . . . . . . 446

C. Alberta AnNounces

THE RENEWABLE Electricity PRogram . . . . . . . . . . . 450

D. Alberta Introduces a PARAllel CAPACITy MARKET . . . . . . 450

IV. The ToOlKit: RenewABle Subsidies AND CAPACITY MECHANISMS . . 451

A. RENEWABle Subsidies . . . . . . . . . . . . . . . 451

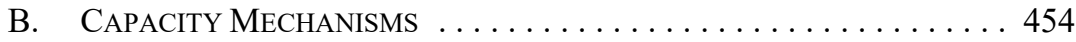

V. NEW RENEWABle ELECTRICITY GENERATION CAPACITY:

ANALYSIS AND COMPARISON OF ALBERTA's NEW REGIME . . . . . . . . . 456

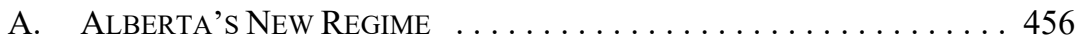

B. INTERNATIONAL COMPARATORS $\ldots \ldots \ldots \ldots \ldots \ldots \ldots \ldots \ldots \ldots$

C. Lessons LeARnEd AND ApPlication to Alberta . . . . . . . . . 473

VI. Transition to a Parallel Capacity Market:

ANALYSIS AND COMPARISON OF ALBERTA's PROPOSALS . . . . . . . . . 486

Cameron Hughes, McCarthy Tétrault LLP and formerly with Dentons Canada LLP; Caitlin Graham, Dentons Canada LLP; Charles July and Adam Brown, Dentons UKMEA LLP; Thomas Schubert, Dentons Europe LLP; and Emma Hand, Dentons US LLP. 


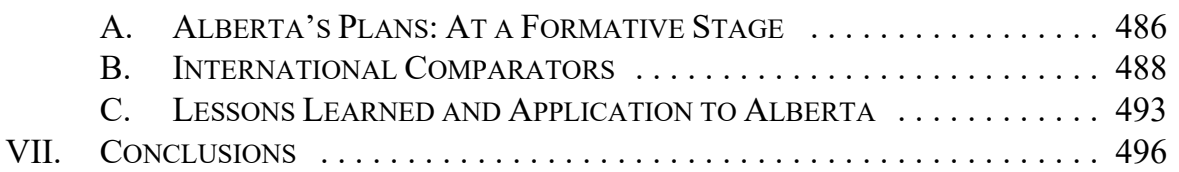

\section{INTRODUCTION}

Starting in late 2015, the Government of Alberta announced a series of initiatives that will fundamentally reshape Alberta's electricity market. These changes are based, in part, on recommendations from the Climate Leadership Panel established by the Alberta government and the Alberta Electric System Operator (AESO). The changes proposed include commitments to retire all coal-fired generation facilities, incentivize 5,000 megawatt (MW) of new renewable generation by 2030, and restructure Alberta's energy-only electricity market to include a parallel capacity market.

These are significant changes for Alberta. However, these types of regulatory interventions have been implemented in a range of other jurisdictions with varying results. Alberta is, as a result, in a position to learn from electricity market reforms in other jurisdictions.

In this article, we examine Alberta's reforms in light of lessons to be learned from Great Britain, Germany, and certain jurisdictions in the United States. We examine both renewable subsidies and capacity mechanisms, with a view to analyzing Alberta's reforms and anticipating expected results, particularly with respect to future investment in Alberta's power infrastructure. As we move away from the invisible hand of the energy-only market to include a more regulated and structured market, will we as Albertans achieve a fair, efficient, and open electricity market that adequately responds to both the needs and the will of our citizens? ${ }^{1}$

\section{Global TrendS}

Like Alberta, jurisdictions around the world recognize a need to reduce carbon emissions. To reduce the carbon footprint of the electricity industry, many jurisdictions subsidize to incentivize the development of renewable electricity generating capacity. These subsidies have taken a number of different forms (see Part IV.A, below) and the extent of the support they have provided has varied widely, but the collective result is stimulation of renewable electricity production. The resulting economies of scale and technical advances, particularly in solar and wind, have led to sharp falls in the cost of renewable technologies and steadily more widespread deployment of renewables. ${ }^{2}$

1 The reforms in Alberta were developing rapidly as we were writing this article. At the time of submission for publication, the first round of tenders for support of new renewable capacity is not complete, and the design of the new capacity market, although progressing rapidly, is still the subject of active and open engagement with stakeholders. What we offer here is therefore necessarily a snapshot of an incomplete process, but we have tried to capture all significant developments up to the date of the Canadian Energy Law Foundation conference in June 2017.

2 See REN21, Renewables 2016 Global Status Report (Paris: REN21 Secretariat, 2016) at 177-79, online: $<$ www.ren21.net/wp-content/uploads/2016/10/REN21_GSR2016_FullReport_en_11.pdf $>$ [Renewables 2016], tables R20 and R21, for a summary account of the global evolution of the most common forms of subsidy. See also Frankfurt School-UNEP Centre/BNEF, Global Trends in Renewable Energy 
Increasingly, new wind and solar generating capacity is now competitive with new gasfired plants when the respective levelized costs of energy are compared. ${ }^{3}$ In very sunny or very windy locations, onshore wind and solar facilities are cheaper to build than combined cycle gas turbines (CCGT). ${ }^{4}$ In Germany, recently plans have been made to generate power using apparently more expensive offshore wind technology without the benefit of a subsidy. ${ }^{5}$ However, the renewables revolution brings with it significant challenges for energy policymakers.

Prior to the introduction of renewables, baseload power came from coal-fired plants (or in some cases nuclear, hydro, ${ }^{6}$ CCGT, or other fossil fuel plants). Peaks in demand were satisfied by bringing on more fossil fuel generation and, in particular, less efficient but quickreacting peaking plants, or pumped storage hydro plants. All of these types of plants are dispatchable, in that they work as part of a dispatchable generation system; they can be turned on and off, and up or down to match demand, with varying effective response times. A MW of generating capacity of one of these technologies may be more or less useful in certain demand conditions than a MW of another, but they are always broadly comparable.

In contrast, renewable wind and solar technologies are not inherently dispatchable. They generate when the wind blows or the sun shines, which may or may not correspond to the demand profile. If these technologies are awarded a subsidy for electricity generated, there is every incentive to generate whenever possible, as there is no marginal cost of operation.

Accordingly, it has become commonplace to talk of the "energy trilemma." The goal in electricity market design is to achieve a system in which electricity supply is secure, sustainable, and affordable. However, any given technology that scores well on one of these objectives presents difficulties for one or more of the other objectives. Nuclear is secure, but expensive, and the secure disposal of its waste products presents a number of challenges. Renewables were considered sustainable but expensive, and are now increasingly viewed as

Investment 2017 at 34 (Figure 25), online: <fs-unep-centre.org/sites/default/files/publications/global trendsinrenewableenergyinvestment2017.pdf $>$. They report that global investment in renewable electricity generating capacity has exceeded US\$270 billion annually in each year from 2010 to 2016 (or in excess of US\$210 billion if large hydro is excluded). This coincides with wind and solar becoming and remaining the dominant technologies in the renewables mix over the same period.

On decreasing costs of renewables, see for example Lazard, "Levelized Cost of Energy Analysis 10.0" (15 December 2016), online: Lazard <https://www.lazard.com/perspective/levelized-cost-of-energyanalysis-100/>.

$4 \quad$ For examples, see Energy Transitions Commission, Better Energy, Greater Prosperity (2017) at Exhibit 6, online: <energy-transitions.org/sites/default/files/BetterEnergy fullReport DIGITAL.PDF>.

These bids relate to projects that are not scheduled to deliver before 2023 . See Ğerman Federal Ministry for Economic Affairs and Energy (BMWi), "Information Portal on Renewable Energies," online: BMWi $<$ www.erneuerbare-energien.de/EE/Navigation/DE/Recht-Politik/EEG-Ausschreibungen/NationaleAusschreibungen/nationale-ausschreibungen.html $>$; Federal Network Agency (Bundesnetzagentur or BNetzA), "Notice of Invitation to Tender Pursuant to Section 29 WindSeeG," online: <https://www. bundesnetzagentur.de/DE/Service-Funktionen/Beschlusskammern/1BK-Geschaeftszeichen-Datenbank/ BK6-GZ/2017/2017_0001bis0999/BK6-17-001/Bekanntmachung_Ausschreibung.pdf?_blob= publicationFile \& $\mathrm{v}=3>$.

6 Hydro power is factually renewable, but many markets do not categorize it as renewable because the production is similar to that of a conventional plant, and because it has been used to generate electricity on a large scale for longer than nuclear or gas technology, let alone other renewable sources, such as wind or solar.

World Energy Council, World Energy Trilemma 2016: Defining Measures to Accelerate the Energy Transition (May 2016), online: <https://www.worldenergy.org/publications/2016/world-energytrilemma-2016-defining-measures-to-accelerate-the-energy-transition/>. 
an inexpensive ${ }^{8}$ but insufficiently secure source of power supply. Fossil fuels score well on security and affordability, but obviously less well on sustainability, even if carbon capture and storage (CCS) is taken into consideration.

There is no simple solution to these challenges. Technology may provide a silver bullet at some point. In the meantime, regulation can only try to strike a reasonable balance between the advantages and disadvantages of different technologies, typically favouring (explicitly or implicitly) one horn of the trilemma over the others, as government policy dictates.

Electricity market design and policy considerations are far-reaching and include:

- Supply mix, and establishing the desired mix of generating technologies. Should percentage targets be set in terms of electricity generated by particular technologies, to be attained by particular dates? ${ }^{9}$

- Interventions to incentivize renewable generation. Unless the state directly procures new generating capacity, the achievement of a specific generating mix objective depends on other forms of intervention in the operation of the market. Different interventions tend to set off a chain reaction of trilemma effects. For example, production-based subsidies for renewable facilities create a substantial amount of capacity that will offer power for sale at low prices. This depresses wholesale market prices generally, and undermines the investment case for other types of generation, including new CCGT plants (which, unlike wind or solar plants, have fuel generation costs).

- $\quad$ Establishing sufficient baseload. If, in the absence of state guarantees, new nuclear plants are prohibitively expensive, and any existing or future coal-fired plants are shut down for environmental or economic reasons, how is baseload generated? In Alberta, should we rely on indigenous supplies of gas, with or without contribution from alternative sources, such as hydro or geothermal resources?

- $\quad$ Meeting peak demand. In order to satisfy periods of peak demand, can we rely on very high market prices during those periods to stimulate investment in new peaking capacity, or is some form of subsidy for dispatchable capacity required?

The relative costs of renewables and fossil fuel generation plants vary significantly with geography. Where, as in Alberta, abundant quantities of fossil fuels are extracted close to sources of electricity demand, and neither wind nor solar resources are exceptionally strong, they continue to enjoy a natural price advantage even when measured on a levelized cost basis.

9 See Renewables 2016, supra note 2 at 165-76, tables R17-R19, for a global summary of renewable electricity generation targets that have been set at national and other levels (including for specific technologies). 
- Incentivizing generation to meet peak demand. If peak capacity is to be incentivized by means of a capacity mechanism, should the incentive mechanisms show any preference as between the different ways of providing capacity? For example, a new grid-connected power station, on-site industrial use generating capacity at times when the system is under strain and demand threatens to exceed supply, or a firm offer by that industrial customer to simply turn off its plant during such periods?

- Accommodating emerging technology. What view should be taken of emerging technologies, which could radically alter the way the market works during the economic lifetime of any new generating plant installed today? Arguably, a fossil fuel plant could be made more sustainable by the addition of CCS technology, while intermittent renewables (solar and wind) could be made more secure by linking them to large-scale energy storage facilities. How quickly will these developments occur without subsidy or other regulatory intervention, and what, if anything, should be done to stimulate emerging technology?

- Regulatory certainty. Given the rapid pace of technological change, and the fact that investors value regulatory stability, what is the best framework for incentives that will not require major adjustments in response to the likely range of future changes in market conditions?

Although the general questions outlined above are asked in respect of markets around the world, specific features of individual markets must be taken into consideration before importing approaches that have been used elsewhere, or which exist only in the pages of an economics textbook and not in a real market.

We begin by considering the particular features of the electricity market in Alberta as it has developed to date, and reviewing recent market reforms (Part III). We then review the range of options to support new generating capacity (Part IV). Next, we analyze Alberta's proposals to support renewable capacity in more detail on a comparative basis with other jurisdictions responding to similar challenges. In doing so, we identify lessons learned that may apply to Alberta (Part V). Finally, we turn to a discussion of Alberta's proposed transition to a parallel capacity market, including a comparative analysis with other jurisdictions responding to similar challenges, and identify lessons learned for Alberta (Part VI).

\section{Alberta: \\ BaCkground And Recent Policy Developments}

\section{A. The First 20 Years of Alberta's ENERGY-ONLY MARKET}

Alberta is currently the only Canadian jurisdiction with an energy-only electricity market. Unlike the Crown monopolies in British Columbia, Manitoba, Quebec, and Saskatchewan, and the hybrid approach in Ontario, Alberta's market relies on competition between generators to ensure an adequate and secure supply of electricity. The wholesale electricity 
market is managed by the AESO, a not-for-profit entity that acts as the independent system operator (ISO) for Alberta, ${ }^{10}$ managing and operating the Alberta Interconnected Electric System (AIES).

Prior to 1996, Alberta's electricity market was served by three vertically-integrated utilities. A central regulator determined electricity rates using a cost of service model. ${ }^{11}$ Deregulation began in 1995 with the introduction of the Electric Utilities Act, ${ }^{12}$ which legislated a new structure for the electricity industry. ${ }^{13}$ A significant area of reform under the EUA (1995) was the development of a competitive market for generation with fair, efficient, and open competition among market participants. ${ }^{14}$

The reforms under the EUA (1995) established the Power Pool Council ${ }^{15}$ to manage the wholesale electricity market, including all electricity entering or leaving the AIES ${ }^{16}$ and financial settlement for all electricity exchanged..$^{17}$ Each regulated generating unit was required to produce a unit obligation amount of electricity to offer into the power pool, the real time spot market for electricity. ${ }^{18}$ Encouraging competitive electricity generation was an ongoing focus as electricity industry deregulation continued in the early $2000 \mathrm{~s} .{ }^{19}$

In 2005, Alberta's Department of Energy reviewed its electricity market framework. Stakeholders strongly opposed long-term market design imposing capacity-based contractual obligations, and the energy-only market was retained. A review of the market carried out by the Brattle Group for the AESO, published in 2011 (and updated in 2013), concluded that, even allowing for additional pressures of meeting climate change policies then in force, and accommodating significant wind power generation, fundamental change to the energy-only market was not necessary. ${ }^{20}$

Electric Utilities Act, SA 2003, c E-5.1, s 20 [EUA 2003].

11 Alberta Electric System Operator, "Guide to Understanding Alberta's Electricity Market" (2016), online: $<$ https://www.aeso.ca/aeso/training/guide-to-understanding-albertas-electricity-market/>. SA 1995, c E-5.5 [EUA (1995)]. Alberta, Legislative Assembly, Hansard, 23rd Leg, 3rd Sess (2 May 1995) at 1488.

Ibid.

EUA (1995), supra note 12, s 7. The Power Pool Council was the independent system operator introduced by the EUA (1995) and the predecessor to the AESO.

EUA (1995), ibid, ss 11-14.

Ibid, s 13(b).

Ibid, s 32 .

Statutory amendments were introduced in 1998 through the Electric Utilities Amendment Act, SA 1998, c 13 [EUAA]. This introduced power purchase arrangements (PPA) on maximum terms of twenty years, to further encourage efficient investment decisions by utilities. See EUAA, ibid, Part 4.1; Alberta, Legislative Assembly, Hansard, 24th Leg, 2nd Sess (16 March 1998) at 920. Full deregulation was achieved in 2001 when the first PPA auction was held.

20 The Brattle Group, Evaluation of Market Fundamentals and Challenges to Long-Term System Adequacy in Alberta's Electricity Market (April 2011), online: <www.brattle.com/system/publications/pdfs/000/ 004/829/original/Evaluation_of_Market_Fundamentals_and_Challenges_to_Long-Term_System_

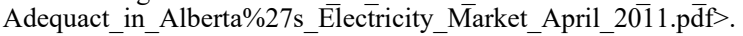


Generators participate in the electricity market by submitting hourly offers to the power pool for a specified quantity of electricity in MW for a specified price (\$/megawatt hour $(\mathrm{MWh})) .{ }^{21}$ Generators above a minimum threshold of $5 \mathrm{MW}$ are required to offer all of their electricity to the power pool in the absence of an acceptable operational reason not to do so (the "must offer, must comply" rule). ${ }^{22}$ Generation is then dispatched in economic merit order - from the lowest to the highest priced offer - to meet real time demand. A System Marginal Price (SMP) is set every minute by the last eligible dispatched generation. ${ }^{23}$ The wholesale market price, referred to as the pool price, is determined on an hourly basis set by the weighted average of the 60 SMPs over the hour. ${ }^{24}$

Alberta's wholesale electricity market also includes a market for ancillary services. ${ }^{25}$ Ancillary services are offered by generators one day in advance and include operating reserves, ${ }^{26}$ transmission must-run, ${ }^{27}$ black start,${ }^{28}$ and load shed services for imports. ${ }^{29}$ The AESO is the monopoly buyer of ancillary services and electricity sold to the power pool. However, electricity is frequently traded in Alberta's electricity market through direct sales agreements and forward contracts. ${ }^{30}$ The wholesale market price set by the pool mechanism serves as a point of reference for the prices in these contracts.

Under the energy-only market, the sale of power and ancillary services are a generator's only source of revenue. Therefore, it is the wholesale market price that provides the only incentive for developers to bring forward new generation projects. Market clearing pool prices will be set by the least efficient generators, creating an incentive to build new, more efficient, generators. Investment in capacity is more likely to happen if there are frequent spikes in the wholesale price at times of high demand. In Alberta, pool prices have recently reached record lows. In 2015, average pool prices fell 33 percent from $2014 .{ }^{31}$ In 2016, average pool prices fell an additional 45 percent from 2015 levels. ${ }^{32}$

These low pool prices, coinciding with significant policy changes from the Alberta government related to climate change initiatives, put the future of Alberta's energy-only electricity market into question.

These are referred to as price-quantity pairs. See Alberta Electric System Operator, ISO Rules (9 January 2017), s 203.1 3(3), online: <https://www.aeso.ca/rules-standards-and-tariff/iso-rules/complete-set-ofiso-rules/>. See also Alberta Electric System Operator, "Determining the Wholesale Market Price for Electricity" (2016), online: <https://www.aeso.ca/download/listedfiles/Wholesale-Market-Price-FactSheet-020311.pdf $>$.

ISO Rules, ibid, s 203.1.

Ibid, s $201.63(1)$.

Ibid, s 201.64.

The EUA 2003 defines ancillary services as those services required to ensure that the interconnected electric system is operated in a manner that provides a satisfactory level of service with acceptable levels of voltage and frequency (see EUA 2003, supra note 10, s 1(1)(b)).

ISO Rules, supra note 21, ss 205.1-205.3.

Ibid, s 205.8 .

Ibid, s 305.3 .

Ibid, s 303.1.

Direct sales agreements and forward contracts must be in accordance with the ISO Rules (see EUA2003, supra note 10, s 19(2)).

Alberta Electric System Operator, "AESO 2015 Annual Market Statistics” (March 2016) at 3, online: $<$ https://www.aeso.ca/assets/listedfiles/2015-Annual-Market-Stats-WEB.pdf $>$.

Alberta Electric System Operator, "AESO 2016 Annual Market Statistics" (February 2017) at 3, online: $<$ https://www.aeso.ca/market/market-and-system-reporting/annual-market-statistic-reports/> [AESO, "Market Statistics"]. 


\section{B. The Climate Leadership Plan Challenges the ENERgy-Only MARKet}

\section{INTRODUCTION TO THE Climate LEADERShIP PlaN}

On the heels of the unprecedented May 2015 election of the New Democratic Party in Alberta, Premier Rachel Notley's majority government formed the Climate Leadership Panel $^{33}$ (the Panel) to provide advice to the province to "inform the development of a comprehensive climate change strategy." 34 The Panel issued the Climate Leadership Report to Minister Phillips in November 2015, shortly before the 21st Conference of the Parties to the United Nations Framework Convention on Climate Change meeting in Paris. ${ }^{35}$

Key recommendations from the Report fed into the government's Climate Leadership Plan (CLP). The CLP is the made-in-Alberta strategy to reduce carbon emissions, designed to meet the needs of the Alberta economy. ${ }^{36}$

Key aspects of the CLP include an economy-wide carbon tax, a 100 megaton cap on oil sands emissions, and a reduction in methane emissions by 45 percent from 2014 levels by 2025. Particularly relevant for our present purposes are two further points: a phase-out of all of Alberta's coal-fired generation assets by 2030, and a plan to replace two thirds of coalfired generation with renewable energy by 2030, the remainder being replaced by gas-fired generation. ${ }^{37}$ Replacing two thirds of coal-fired generation with renewable generation by 2030 would achieve the " 30 by 30 " target, whereby 30 percent of Alberta's electricity is produced using renewable fuel. ${ }^{38}$

While we note that the common perception is that Alberta's market reform proposals are substantially based on recommendations of the Panel, some commentators have suggested that relatively few of the policy actions in the CLP came out of the Panel's recommendations. For example, the Panel recommended that a carbon tax should be applied to coal with the compliance standard set at a "best gas" standard, with the standard raised as natural gas efficiencies improved, or at 2 percent per year, so that coal is forced to economically retire by $2030 .^{39}$ Instead, the Government of Alberta elected only to require physical retirements in 2030. In addition, the Government of Alberta is currently working to make "output-based allocations," 40 which may or may not reflect the best gas standard. The Panel did not recommend restructuring of the market; rather, the Panel's recommendations were envisaged to occur within the existing energy-only market.

The Panel was formed in the summer of 2015.

Alberta, Climate Leadership Panel, Climate Leadership: Report to Minister (20 November 2015) at 13, online: $<$ https://www.alberta.ca/documents/climate/climate-leadership-report-to-minister.pdf $>$ [Report]. These meetings were held in December 2015. See United Nations Framework Convention on Climate Change, online: <unfccc.int/meetings/paris nov 2015/meeting/8926.php>.

Government of Alberta, "Climate Leadership Plan," online: $<$ https://www.alberta.ca/climate-leadershipplan.aspx\#toc-0>.

Government of Alberta, "Climate Leadership Plan Will Protect Albertans' Health, Environment and Economy" (22 November 2015), online: <https://www.alberta.ca/release.cfm?xID=38885E74F7B63A62D-D1D2-E7BCF6A98D616C09>.

Government of Alberta, "Renewable Electricity Program" (2017), online: <https://www.alberta.ca/ renewable-electricity-program.aspx $>$.

Report, supra note 34 at 6.

Ibid at $48,94$. 
The CLP will have significant implications for Alberta's electricity market, notably:

- The changes in generating mix to be achieved by 2030 are considerable. In 2016, coal-fired generation supplied almost two thirds of the system load in Alberta, while gas-fired generation supplied 27 percent, and renewable generation supplied 11 percent. $^{41}$

- New coal-fired generation capacity has come into service in Alberta as recently as $2012 .{ }^{42}$ A total of 2.6 gigawatts $(\mathrm{GW})$, or more than 40 percent of this coal-fired generating capacity, would not otherwise be scheduled to close until after 2036 (and in some cases, much later).

- As noted above, a GW of intermittent renewable generation is not functionally equivalent to a GW of coal-fired or gas-fired generation. Fossil fuel plants are dispatchable, and are inherently more capable of responding to market signals than wind farms. To date, most Alberta wind power is located in the same part of the province, so at any given time the assets are either all generating power or producing little to no power.

- $\quad$ As the Panel identified, rapid retirement of coal-fired plants without introducing sufficient new gas-fired generation leads to system reliability risks. ${ }^{43}$

- At present, coal-fired units tend to set the pool price most of the time, operate as base load, and contribute to the current relatively low wholesale electricity market prices. Without coal-fired plants, gas-fired plants would run as base load and typically set the pool price (although different types of gas-fired generation, such as CCGT or simple cycle, would set the pool price with differing levels of frequency). ${ }^{44}$

- Wholesale prices might be expected to rise where gas-fired generation sets pool prices, as these generators may be more expensive to run than old, fullydepreciated, coal-fired generating assets. However, wind power has zero marginal cost: having more of it on the AIES will reduce wholesale prices. 


\section{The Current Status of Alberta’s Renewable ELECTRICITY GENERATING CAPACITY}

Table 1 shows that Alberta has a material amount of renewable electricity generating capacity, and in particular, wind power. Renewables (or at least wind) have not been incentivized by the textbook stimulus of high wholesale market prices which has, or ought to have, caused new coal and gas-fired plants to be built. ${ }^{45}$

TABLE 1:

ALberta's CURRENT EleCtricity Generating Mix ${ }^{46}$

\begin{tabular}{|l|c|c|c|c|}
\hline \multicolumn{1}{|c|}{ Energy Source } & $\begin{array}{c}\text { Generation } \\
(\mathbf{G w h})\end{array}$ & $\begin{array}{c}\text { Share of } \\
\text { Generation }\end{array}$ & $\begin{array}{c}\text { Installed } \\
\text { Capacity (MW) }\end{array}$ & $\begin{array}{c}\text { Share of } \\
\text { Installed Capacity }\end{array}$ \\
\hline Coal & 41378 & $51 \%$ & 7081 & $44 \%$ \\
\hline Natural Gas & 32215 & $39 \%$ & 6267 & $39 \%$ \\
\hline Hydro & 1745 & $2 \%$ & 902 & $6 \%$ \\
\hline Wind & 3816 & $5 \%$ & 1491 & $9 \%$ \\
\hline Biomass & 2149 & $3 \%$ & 424 & $3 \%$ \\
\hline Solar \& Others & 318 & $0 \%$ & 97 & $1 \%$ \\
\hline TOTAL & 81621 & $100 \%$ & 16261 & $100 \%$ \\
\hline
\end{tabular}

The province's electricity market has never included a renewable portfolio standard (RPS) or feed-in-tariff (FiT) scheme (see Part IV.A, below). However:

- Some older renewable projects in Alberta have received support from other programs, including the Wind Power Production Incentive (which closed in 2007) and its successor, the ecoEnergy for Renewable Power program (which closed in 2011). Both of these programs provide a cents per kilowatt hour (kWh) subsidy of between 0.8 and 1.2 cents per $\mathrm{kWh} .^{47}$

- Some projects have benefited from favourable treatment under federal income tax rules, which allow the value of certain equipment to be deducted, or written off at an accelerated rate. ${ }^{48}$

Wind and solar have historically faced higher per MW capital costs than fossil fuel generation. AESO figures show that on an annual average basis, electricity generated from wind achieves a discount to the pool price. Electricity generated by other technologies generally, on an annual basis, achieves a premium to the pool price (and in some cases, a significant premium to that price). See AESO, "Market Statistics," supra note 32 at 12 , Figure 12.

46 Government of Alberta, "Electricity Statistics: Electricity Supply"(2016), online: <www.energy.alberta. $\mathrm{ca} /$ Electricity/682.asp $>$. The generation figures are dated December 2015 ; the installed capacity figures are dated June 2016.

47 Natural Resources Canada, "Wind Power Production Incentive Contribution Program" (2016), online: <www.nrcan.gc.ca/plans-performance-reports/rpp/2015-16/17057; Natural Resources Canada, "ecoENERGY for Renewable Power" (2016), online: <www.nrcan.gc.ca/ecoaction/14145>.

48 Natural Resources Canada, "Tax Savings for Industry" (2017), online: <www.nrcan.gc.ca/energy/ efficiency/industry/financial-assistance/5147>. 
- $\quad$ Some projects are investments by electricity generators, which enables them to reduce the intensity of their overall greenhouse gas emissions, so as to meet their targets under Alberta's 2007 Specified Gas Emitters Regulation by generating carbon offset credits. ${ }^{49}$

- Some projects have been able to monetize their renewable attributes or renewable energy certificates - for example, those issued under the Western Renewable Energy Generation Information System (WREGIS) - to utilities in jurisdictions, such as California, where the purchase of such certificates enables them to meet an applicable RPS. ${ }^{50}$

The lack of new projects being built over the last two years ${ }^{51}$ may signal that these renewable project incentives are either no longer available, or are insufficient to stimulate the kind of growth in renewable electricity generating capacity that Alberta is targeting. Conversely, the lack of investment may simply reflect uncertainty with respect to energy policy and electricity market structure and regulation.

To incentivize renewable generation growth, the Panel recommended a competitive request for proposals for government support through renewable energy credits (RECs). The government would purchase the renewable attributes of the power on a long-term contract. ${ }^{52}$ The Panel recommended a price collar on support of $\$ 35 / \mathrm{MWh}$ to limit the government's exposure to high costs of support, and signal the requirement for competitive renewable generation. ${ }^{53}$

Following the CLP announcement, in January 2016 the Government of Alberta tasked the AESO with developing and implementing a plan to bring on new renewable electricity generation capacity by 2030 , using a competitive process, and in concert with the retirement of coal-fired generating units. ${ }^{54}$ Following research and engagement, including a third-party review of renewable procurement programs in other jurisdictions, ${ }^{55}$ the AESO submitted its Renewable Electricity Program (REP) Recommendations to the Government of Alberta in May $2016 .{ }^{56}$

Specified Gas Emitters Regulation, Alta Reg 139/2007.

John Goetz, "The Impact of Offsets and REC's on the Economics of Wind Projects in Alberta" (Presentation delivered at the 2011 Canadian Wind Energy Association (CanWEA) Annual Conference, Vancouver, 6 October 2011), online: $<$ https://www.slideshare.net/fmclaw/impact-of-offsets-and-recs-oneconomics-of-alberta-wind-projects-canwea-october-6-2011>.

Generation Additions, supra note 42.

Report, supra note 34 at 49.

Ibid at 50

Letter from Grant D Sprague, Deputy Minister of Energy, Alberta to David Erickson, President and CEO, AESO (26 January 2016), online: AESO <https://www.aeso.ca/assets/Uploads/goa-letter-jan 26.pdf>.

55 London Economics International LLC, "Case Studies of Jurisdictions With Centralized Procurement to Encourage the Development of Renewable Generation" (1 April 2016), in Alberta Electric System Operator, Renewable Electricity Program Recommendations (May 2016) at Appendix D, online: $<$ https://www.aeso.ca/assets/Uploads/AESO-RenewableElectricityProgramRecommendationsReport.pdf $>$ [AESO, REP Recommendations].

56 AESO, REP Recommendations, ibid. See also Government of Alberta, "Renewable Electricity Plan to Create Jobs, Spur Investment" (3 November 2016), online: $<$ https://www.alberta.ca/release.cfm?xID= 43752ABFE959B-9AD9-9E3C-DBFCF5B5CA13C24C > [Government of Alberta, "Investment"]. 


\section{Alberta Announces the Renewable Electricity Program}

On 3 November 2016, the Government of Alberta publicly released and adopted the REP Recommendations and introduced the Renewable Electricity Act ${ }^{57}$ to implement the REP. The REP aims to incentivize the addition of 5,000 MW of renewable generation to the Alberta electricity market by 2030 , to meet the 30 by 30 target. This is the equivalent of adding, on average, 400 to $500 \mathrm{MW}$ of new capacity each year from 2019. The intended capacity additions would be about four times as much as was added, on average, in new wind power projects each year over the 2007-2016 period. ${ }^{58}$ The government estimates that the REP will result in $\$ 10.5$ billion of investment in Alberta, and create at least 7,200 jobs. ${ }^{59}$

The Renewable Electricity Act is the basis for the AESO's authority with respect to the REP. It directs the AESO to develop a renewable electricity program to promote large-scale renewable electricity generation in the province using a competitive process, consistent with the safe, reliable, and economic operation of the AIES. ${ }^{60}$ The AESO is also required to administer the competitive procurement process in accordance with the program it develops. ${ }^{61}$ The object of the REP is to deliver a significant increase in renewable electricity generating capacity, within a specified period of time, at as low a cost as possible. ${ }^{62}$

In taking these steps, the Alberta government expressly stated that it did not intend to alter Alberta's electricity market structure. ${ }^{63}$ For the first time, however, developers of large-scale new renewable electricity generating capacity in Alberta were on course to receive a significant amount of revenue in the form of subsidy payments mandated by the authorities in their own province. ${ }^{64}$

\section{Alberta Introduces a Parallel Capacity Market}

Despite the Alberta government's decision not to fundamentally alter the wholesale electricity market structure when it announced the REP, it was recognized that establishing a significantly enhanced renewables sector, dominated by intermittent power generation from wind, could threaten the overall reliability of the market. With additional new wind power capacity driving wholesale prices down, the ability of the energy-only market to stimulate the development of enough new gas-fired capacity to counterbalance this volatility and maintain system reliability would be inadequate.

\footnotetext{
SA 2016, c R-16.5.

Generation Additions, supra note 42.

Government of Alberta, "Investment," supra note 56.

Renewable Electricity Act, supra note 57, s 3. The proposal would be subject to ministerial approval (see ibid, s 5).

Ibid, $\mathrm{s} 7$.

AESO, REP Recommendations, supra note 55 at 1.

Ibid.

The REP proposals apply only to projects of at least $5 \mathrm{MW}$; see AESO, REP Recommendations, supra note 55 at 9 . There are other Government of Alberta support schemes for smaller renewable (solar) projects, but for the moment these appear to be limited in scope (Micro-Generation Regulation, Alta Reg 27/2008). Links to details of the Alberta Municipal Solar Program, the On Farm Solar PV Program, and the Residential and Commercial Solar Program are online: $<$ https://www.alberta.ca/release.cfm?xID= 46587792EBC50-B485-6F9B-A32E01982689B5CF>.
} 
In response to this concern, on 23 November 2016, the Government of Alberta introduced its decision to restructure the electricity market to include a capacity market. ${ }^{65}$ This decision was based on a recommendation of the AESO and the AESO's independent third party advisors, after assessing the long-term sustainability of Alberta's current electricity market structure with the changing supply mix. ${ }^{66}$

In this recommendation, the AESO reasoned that adding high volumes of intermittent renewable generation to the AIES, when pool prices were already low, would decrease revenue available for generators. The AESO concluded that there is substantial uncertainty about whether sufficient investment in non-renewable generation will occur in Alberta in the future to ensure reliable electricity supply. The AESO considered alternatives to the energyonly market structure, and concluded that a parallel capacity market was the optimal solution to the system reliability concern.

\section{THE TOOLKIT: \\ RENEWABLE SubSIDIES AND CAPACITY MECHANISMS}

\section{A. Renewable Subsidies}

The State can provide support for the deployment of renewable generation in many ways, including tax breaks on investments in renewable projects, loan guarantees and other forms of credit support, direct grants, and the facilitation of projects by transferring part of the costs and risks typically associated with a power project away from the project developer. An example of transferring costs and risk is to offer developers access to sites which have already been zoned or consented to for development.

All these methods have been successfully applied in a number of jurisdictions, and have contributed significantly to the development of renewables sectors. We do not consider these support mechanisms further in this article, as they are not consistent with the mechanisms proposed in Alberta. Instead, we focus on the internationally dominant group of techniques for boosting the revenues of renewable electricity generation projects (income supports), and on the related techniques adopted for ensuring that they have a route to market for the power that they produce (offtake supports). A general description of these supports is set out in Table 2, below. 2016), online: <https://www.alberta.ca/release.cfm?xID=44880BD97DCDC-D465-4922-25225F9F43 B302C $>$.

66 Alberta Electric System Operator, Alberta's Wholesale Electricity Market Transition Recommendation (3 October 2016), online: <https://www.alberta.ca/documents/Electricity-market-transition-report.PDF> [AESO, Transition Recommendation]. 
TABLE 2:

SUMMARY TYPOLOGY OF RENEWABLE ELECTRICITY GENERATION INCOME AND OFFTAKE SUPPORT ${ }^{67}$

\begin{tabular}{|c|c|c|}
\hline Category & Main Scheme-Specific Variants/Features & $\begin{array}{l}\text { Offtake Support and Further } \\
\text { Comments }\end{array}$ \\
\hline $\begin{array}{l}\text { Fixed FiT: eligible } \\
\text { renewable generation } \\
\text { projects are paid under a } \\
\text { tariff per MWh of } \\
\text { electricity produced }\end{array}$ & $\begin{array}{l}\text { "Classic FiT": FiT regimes, insulate } \\
\text { generators from risk associated with wholesale } \\
\text { market price volatility. Generators are paid } \\
\text { pursuant to a tariff. } \\
\text { "Feed-in premium" (FiP): FiP regimes provide } \\
\text { a fixed level of support to generators in } \\
\text { addition to the wholesale price obtained for the } \\
\text { generator's electricity. } \\
\text { Separate tariffs may be paid for electricity } \\
\text { generated and electricity exported (or deemed } \\
\text { to be exported) to the grid. }\end{array}$ & $\begin{array}{l}\text { Often associated with an obligation on } \\
\text { some or all utilities (or a central buyer) to } \\
\text { take all the renewable generators' power. } \\
\text { The broadest category of support includes } \\
\text { direct procurement of renewables by the } \\
\text { state, as well as competitive bids for FiPs. } \\
\text { The level of both classic FiT and FiP can } \\
\text { be set administratively, or by competition. } \\
\text { Classic FiT is best suited to small } \\
\text { projects: when applied on a large scale, it } \\
\text { disproportionately insulates the generator } \\
\text { market from market forces. } \\
\text { With FiP, generators are at risk if market } \\
\text { prices are lower than expected, but may } \\
\text { be "over-compensated" if they are higher. }\end{array}$ \\
\hline
\end{tabular}

67 The classification presented here uses terms current among policy-makers in the European Union. For example, see Anne Held et al, Best Practice Design Features for RES-E Support Schemes and Best Practice Methodologies to Determine Remuneration Levels (September 2014), online: <https://www. ecofys.com/ files/files/diacore best-practice-design-criteria-and-lcoe 2014 final.pdf $>$; Council of European Energy Regulators, Status Review of Renewable Support Schemes in Europe (11 April 2017), online: $<$ https://www.ceer.eu/documents/104400/-/-/41df1bfe-d740-1835-9630-4e4cccaf8173> [Status Review]. What we have called here "green certificates" are often referred to as a "quota" system. Some authors treat Floating Market Premiums and Variable FiT/CFDs as a single category. Readers may form their own view as to whether they should be distinguished, based on the description of the German and British regimes in Part V.B, below. 


\begin{tabular}{|c|c|c|}
\hline Category & Main Scheme-Specific Variants/Features & $\begin{array}{l}\text { Offtake Support and Further } \\
\text { Comments }\end{array}$ \\
\hline $\begin{array}{l}\text { (Floating) market } \\
\text { premium }\end{array}$ & $\begin{array}{l}\text { Plant operators sell the energy directly, either } \\
\text { by themselves or through a direct marketer, to } \\
\text { the customers in the wholesale market or on } \\
\text { the end customer level. } \\
\text { In addition to the sales revenue obtained, the } \\
\text { operator is entitled to claim a so-called market } \\
\text { premium from the relevant transmission } \\
\text { system operator. } \\
\text { The market premium equals the difference } \\
\text { between the applicable reference price and the } \\
\text { monthly market value (the average actual } \\
\text { monthly value calculated retrospectively of the } \\
\text { source-specific market value of electricity } \\
\text { generated from renewable energy sources on } \\
\text { the spot market). }\end{array}$ & $\begin{array}{l}\text { The direct marketing is carried out } \\
\text { through a direct marketing company, } \\
\text { which is either active as sales } \\
\text { representative, or commission agent, or } \\
\text { principal. }\end{array}$ \\
\hline $\begin{array}{l}\text { Variable FiT and Contract } \\
\text { for Difference (CFD): } \\
\text { generator income is } \\
\text { capped, amount of } \\
\text { subsidy varies with } \\
\text { wholesale market price }\end{array}$ & $\begin{array}{l}\text { Plant operators sell the energy on the } \\
\text { wholesale market, but by a separate CFD } \\
\text { contract with a central counterparty, they are } \\
\text { guaranteed to receive a certain "strike price" } \\
\text { for each eligible MWh of power produced. }\end{array}$ & $\begin{array}{l}\text { Variable FiT and CFD: generators' } \\
\text { income is capped the amount of subsidy } \\
\text { varies with wholesale market price }\end{array}$ \\
\hline $\begin{array}{l}\text { Green certificates: } \\
\text { eligible projects receive } \\
\text { tradable or redeemable } \\
\text { certificates per MWh } \\
\text { produced }\end{array}$ & $\begin{array}{l}\text { There are different mechanisms for generators } \\
\text { to monetize green certificates. } \\
\text { Market and regulatory factors affect value and } \\
\text { price volatility of certificates. } \\
\text { There may be opportunities to trade } \\
\text { certificates in neighbouring markets. }\end{array}$ & $\begin{array}{l}\text { Typically associated with an RPS which } \\
\text { obliges some or all utilities to purchase a } \\
\text { certain number of certificates to drive } \\
\text { demand for renewable electricity in } \\
\text { wholesale markets. }^{68} \\
\text { Generators are at risk if certificate prices } \\
\text { are volatile or fixed too low; the level of } \\
\text { RPS needs to keep pace with issue of } \\
\text { certificates. }\end{array}$ \\
\hline
\end{tabular}

To generalize, US markets have been characterized by a combination of green certificates linked to state-level renewable portfolio standards, and some federal tax breaks. In Europe, most jurisdictions began to subsidize renewables either using classic FiTs or green

68 In a number of European jurisdictions, including Italy, Spain, and Romania, the renewables sector has yet to fully recover from government decisions to reduce the entitlements of subsidy-eligible projects. In Great Britain, the government has maintained a firm policy of grandfathering under the Renewables Obligation (RO) and FiT regimes. Whenever the subsidy levels under these schemes were reduced, the reductions were only applied to schemes that had not yet been accredited. This maintained investor confidence, but even in Great Britain, the move to a system in which the generator's rights are set out in a contract rather than in statute is considered to have been beneficial. 
certificates, but are now moving towards FiPs, (floating) market premiums, or CFDs, allocated by means of competitive tender processes. ${ }^{69}$

In Alberta, the CLP expressly rejected the idea of long-term government-backed power contracts or a FiT scheme, ${ }^{70}$ and the authorities have chosen what is effectively a CFD scheme $^{71}$, even though it also involves the purchase of green certificates from generators.

\section{B. CAPACity Mechanisms}

In a 2016 report issued as part of its investigation into European capacity mechanisms, the European Commission found that over the 2000-2013 period, there was, on average, an increase of just under 10 percent in the share of electricity generated from renewable sources across the EU, and that utilization of combustible fuels in power stations in the EU declined by approximately the same amount. ${ }^{72}$ Governments have adopted different types of capacity mechanisms to address concerns about the perceived under-investment in reliable generating capacity, often linked to the increased penetration of the generating sector by renewables. Table 3, below, summarizes these different mechanisms, based on the European Commission's analysis of the capacity mechanisms, which a number of EU Member States had established, or were in the process of establishing.

For a useful survey, see Status Review, supra note 67 at 10. Under European Union (EU) law, most forms of renewable support schemes and capacity mechanisms are generally classified as forms of state aid and, as such, require prior clearance from the European Commission - failing which, the recipients of aid are compelled to disgorge it (see European Commission, Guidelines on State Aid for Environmental Protection and Energy, 2014-2020(2014), online: <eur-lex.europa.eu/legal-content/EN/ TXT/?uri=CELEX\%3A52014XC0628\%2801\%29> [Commission Guidelines]. The Commission Guidelines treat the competitive allocation procedures as a norm (subject only to limited exceptions) for aid granted from 2017. There is a diversity of approaches among EU Member States: France favours FiPs; the German and Italian regimes are closer to CFDs, as is the Danish offshore wind support scheme; Germany, France, Italy and Greece all use both administrative and competitive techniques to set the support levels for different categories of projects. Provision for the clawing back of "overcompensation," when subsidies are paid on top of market prices and market prices are high, has become commonplace. Most countries apply different subsidy rules to smaller (typically sub-5 MW) and larger plants. For convenient summaries of these regimes, see the state aid clearance decisions relating to them in cases EC, State Aid SA.44666 (2016/N) (Greece): New operating aid scheme for the production of electricity fromRES and HECHP, [2017] OJ, C 83/01; EC, State Aid SA.43756 (2015/N) - Italy: Support to electricity from renewable sources in Italy, [2016] c 258/01; EC, State Aid SA.46655 (2016/NN) France: Complément de rémunération pour l'éolien terrestre en 2016, [2017] OJ, c 51/01; EC, State Aid SA.45461 (2016/N) - Germany: EEG 2017 - Reform of the Renewable Energy Law, [2017] OJ, c 58/01 [Germany SA]; EC, State Aid SA.43751 (2016/N) Denmark: Design and Construction of a 350 MW offshore wind capacity, [2017] c 36/01. Full text of each decsion can be found online: European Commission <ec.europa.eu/competition/elojade/isef/index.cfm>.

70 Report, supra note 34 at 51.

71 The CFD mechanism will not necessarily apply beyond the first (2017) REP auction, and may be replaced with a competitive top-up mechanism more conducive to Alberta's market structure for subsequent auction rounds. This, of course, cannot be done until market rates are finalized. It is believed that the cost to consumers of renewable power will decrease significantly if and when this happens. See AESO, REP Recommendations, supra note 55 at 20.

72 See European Commission, "Report From the Commission: Interim Report of the Sector Inquiry on Capacity Mechanisms" (Brussels: EC, 13 April 2016), Figure 2, s 6.2, online: <ec.europa.eu/ competition/sectors/energy/capacity_mechanism_report_en.pdf $>$; European Commission,CCommission Staff Working Document: Final Report of the Sector Inquiry on Capacity Mechanisms (Brussels: EC, 30 November 2016), s 3.2, online: <ec.europa.eu/competition/sectors/energy/capacity_mechanism_ swd_en.pdf $>$ [Sector Inquiry]. 
TABLE 3:

SUMMARY TYPOLOGY OF CAPACITY MECHANISMS ${ }^{73}$

\begin{tabular}{|c|c|c|}
\hline Category & $\begin{array}{l}\text { Main Scheme-Specific } \\
\text { Variants/Features }\end{array}$ & Further Comments \\
\hline $\begin{array}{l}\text { Targeted scheme: } \\
\text { missing capacity that } \\
\text { is required to } \\
\text { supplement what the } \\
\text { market will provide. } \\
\text { The capacity is } \\
\text { identified and } \\
\text { supported. }\end{array}$ & $\begin{array}{l}\text { Tender for new capacity: procure and } \\
\text { support new capacity, which may operate } \\
\text { in the market as normal as well. } \\
\text { Strategic reserve: top up capacity is } \\
\text { contracted and held outside the market, } \\
\text { only running in specific conditions } \\
\text { (demand-side equivalent is sometimes } \\
\text { called an "interruptibility scheme"). } \\
\text { Targeted capacity payment: price of } \\
\text { capacity is set centrally and paid to } \\
\text { capacity that meets specific criteria. }\end{array}$ & $\begin{array}{l}\text { Among EU countries, targeted } \\
\text { schemes have been more popular } \\
\text { than market-wide schemes, and } \\
\text { strategic reserve has been by far the } \\
\text { most popular variant. } \\
\text { Can be applied to generation or } \\
\text { demand side capacity; can be very } \\
\text { tightly focused (for example, on } \\
\text { procuring a single plant to address } \\
\text { regional security of supply } \\
\text { concerns). } \\
\text { Procurement processes are } \\
\text { sometimes criticized as opaque or } \\
\text { unfair. }\end{array}$ \\
\hline $\begin{array}{l}\text { Market-wide } \\
\text { scheme: all capacity } \\
\text { required to ensure } \\
\text { security of supply is } \\
\text { supported. }\end{array}$ & $\begin{array}{l}\text { Central buyer: total capacity required is } \\
\text { determined centrally and bidding process } \\
\text { between potential providers sets the price. } \\
\text { Decentralized obligation: utilities are } \\
\text { obliged to secure all the capacity required } \\
\text { to meet consumers' demand; market } \\
\text { forces establish price for required volume. } \\
\text { Market-wide payment: price of capacity is } \\
\text { set centrally based on estimates of } \\
\text { payment required to bring forward } \\
\text { required amount of capacity. }\end{array}$ & $\begin{array}{l}\text { Central buyer is the most popular } \\
\text { variant: adopted in Great Britain and } \\
\text { the US. }{ }^{74} \\
\text { Decentralized obligation is found in } \\
\text { France, where it is based around } \\
\text { tradable certificates. } \\
\text { Can be applied to generation or } \\
\text { demand side capacity, but care } \\
\text { needs to be taken to create a level } \\
\text { playing field between technologies } \\
\text { (just paying a subsidy to the whole } \\
\text { market does not achieve this). }\end{array}$ \\
\hline
\end{tabular}

As with renewable support schemes, our comparative analysis will focus on examples of capacity mechanisms that most closely correspond to the type of scheme under consideration in Alberta, which appears likely to be a central buyer regime. Comparisons will be drawn with British, German, and certain US regimes. 


\section{NEW RENEWABLE ELECTRICITy GENERATiON \\ CAPACITY: ANALYSIS AND COMPARISON of Alberta's NeW REgime}

The key features of the renewable subsidy system being developed for Alberta are described in Part V.A, below. Significant points of comparison in the CFD regimes of Great Britain and Germany, contrasted with the US position, can be found in Part V.B, below. Lessons learned from the experiences of other jurisdictions relevant to the developing regime in Alberta are summarized in Part V.C, below.

\section{A. Alberta's New Regime \\ 1. INTRODUCTION}

An outline of the regime that is being put in place under the Renewable Electricity Act is as follows:

- $\quad$ support for new renewable generating projects is to take the form of payments made in exchange for renewable attributes/RECs;

- the amount of the payments is the difference between a predetermined "strike price" (bid by the generator in a competitive process) and the pool price for electricity for a given period ${ }^{75}$

- $\quad$ payments flow to the generator when the pool price is below the strike price, and from the generator when the pool price is above the strike price;

- generators may only sell their power into the pool: they may not enter into any bilateral arrangements with respect to the output of a REP-supported facility;

- $\quad$ successful bidders will be awarded a Renewable Electricity Support Agreement (RESA) enshrining this support;

- $\quad$ payments are to be made in respect of each MWh generated by a given project over a certain number of years; and

- in return for the financial benefits it receives under the strike price mechanism, the generator gives up the possibility of monetizing its renewable attributes, which are to be transferred to the AESO. 


\section{PAYMENT MECHANISM}

As noted in Part IV, above, a CFD support scheme enjoys significant advantages over a FiT, FiP, or green certificate scheme of renewables support. The REP Recommendations highlighted three possible payment mechanisms to govern the RESA:

- $\quad$ A FiT-style Fixed REC mechanism, under which a winning bidder will receive a $\$ / M W h$ payment as bid on top of the revenue received from the energy market for dispatched electricity, to close the gap between the pool price and the project cost. ${ }^{76}$

- $\quad$ A CFD-style Indexed REC mechanism, where a winning bidder is paid a \$/MWh payment based on the difference between the bid price or strike price, and the pool price. The strike price is essentially the lowest acceptable cost for the project. ${ }^{77}$

- Capacity payments, which were discounted at an early stage, ${ }^{78}$ such that the REP was designed to accommodate either a Fixed REC or Indexed REC payment mechanism. $^{79}$

As noted above, the CLP proposed a Fixed REC capped at $\$ 35 / \mathrm{MWh}$. The AESO indicated that a capped Fixed REC may limit the number of bidders by limiting financing options. A Fixed REC pricing mechanism would be "unlikely to provide sufficient revenue certainty required for project financing schemes unless the Fixed REC is uncapped." ${ }^{\circ 0}$ An uncapped Fixed REC would produce its own challenges, such as possibly limiting procurement due to provincial budget constraints, which could impede meeting the 30 by 30 target. ${ }^{81}$

From a cost-control point of view, the key advantage of the Indexed REC occurs when the pool price exceeds the strike price, and the generator pays the Alberta government the difference via the AESO. This means that generators do not receive any more revenue per MWh than is implicit in their strike price. ${ }^{82}$ From a bidder's point of view, knowing that it will not benefit from merchant price opportunity may make it easier to calculate an acceptable strike price. The AESO determined that an Indexed REC payment mechanism would likely attract more bidders than a capped Fixed REC, based on an assessment of their ability to finance projects under the two alternatives. ${ }^{83}$

AESO, REP Recommendations, supra note 55 at 16.

Ibid.

The AESO considered a capacity payment mechanism whereby a winning bidder is paid a $\$ / M W h$ for capacity built. The AESO stated this was the least favourable pricing mechanism, citing the fact that bid up capacity payment prices would receive financing due to the low pool price, the inconsistency between dispatch of intermittent generation and a capacity payment which provides compensation for availability, and windfall gains to generators as pool prices rise over time (see ibid at 17).

Ibid at 20 .

Ibid at 18 .

Ibid at 20 .

Ibid at 16 . Winning projects will bid a price that is effectively the lowest acceptable cost for the renewable project. Pursuant to the RESA, the support paid to the generator is the difference between the pool price and the strike price. As an example, if the bid price is $\$ 80 / \mathrm{MWh}$ and the pool price is $\$ 30 / \mathrm{MWh}$, the AESO will pay the generator the $\$ 50 / \mathrm{MWh}$ difference. 
The REP will be funded by the carbon levy, which is anticipated to raise $\$ 1$ billion in 2017-2018. ${ }^{84}$ Comparing the cost of using a Fixed and Indexed REC, the AESO noted that a Fixed REC has the potential to cost the Alberta government significantly more in support payments. As the risk associated with pool price is borne by investors or developers under a Fixed REC, risk premiums would likely be included in bids to account for pool price uncertainty if support is not capped. ${ }^{85}$

The Indexed REC mechanism allocates the risk of pool price volatility to the Alberta government. As a result, price uncertainty would have a less marked impact on levels of support required under an Indexed REC. ${ }^{86}$ An additional consideration, as noted above, is that a Fixed REC allows the investor or developer to retain all revenue from the energy market, even where pool prices are higher than the bid price. A higher-than-bid pool price under the Indexed REC offsets the support payment amount, resulting in a decreased cost to the Alberta government. ${ }^{87}$

Although the Indexed REC approach has been chosen for the first auction, the AESO does not expect that either pricing mechanism would fundamentally alter the current electricity market structure ${ }^{88}$ and it has left open the possibility that future auctions could use the Fixed REC payment mechanism.

\section{SELECTING PROJECTS FOR SUPPORT}

The REP Recommendations proposes a series of two or three stage competitions between 2016 and 2030 for government support for renewable projects. The three generic stages for each competition include a Request for Expressions of Interest (REOI), a Request for Qualifications (RFQ), and a Request for Proposals (RFP). ${ }^{89}$ The process is to be overseen by a third party fairness advisor with the right to disqualify bidders engaged in anti-competitive behaviour, such as collusion. ${ }^{90}$

The REOI for the first competition of the REP (Round 1) was published on 31 March 2017. ${ }^{91}$ Its stated purpose is to assist the AESO in identifying those interested in participating

Government of Alberta, "Revenue" (2017), online: <https://www.alberta.ca/budget-revenue.aspx>; Renewable Electricity Act, supra note 57, s 12.

85 AESO, REP Recommendations, supra note 55 at 22.

86 A bidder in a Fixed REC scheme many consider it necessary to inflate the amount which it bids to be awarded on top of the market price because the market price may be very low, and it has no other means of assuring the desired level of income. However, in an Indexed REC scheme, the bidder is assured of receiving the strike price (subject only to a discount to the extent that it is unable to sell its power for an amount at least equal to the pool price) (see ibid at 22).

Ibid at 22.

Ibid at 18

The Renewable Electricity Act, supra note 57, does not specify any detail of the competitive process. It merely provides, in very broad terms, for the AESO to administer the process in accordance with criteria and procedures that have been approved by the Minister. No specific provision is made for matters such as criteria for evaluating bids to be the subject of consultation before they are approved. However, a variety of matters, including "the development of renewable electricity program proposals and the implementation of renewable electricity programs" may be the subject of regulations (ibid, s $18(d))$. Regulations prescribing aspects of the competitive process have not been developed to date. See ibid, ss 7(1), 18 .

90 AESO, REP Recommendations, supra note 55 at 14. See also Renewable Electricity Act, ibid, s 6.

91 Alberta Electric System Operator, "Request for Expressions of Interest for the first Renewable Electricity Program Competition: REP Round 1" (31 March 2017), online: <https://www.aeso.ca/ assets/Uploads/REP-Round-1-REOI-033117.pdf> [REOI]. 
in the RFQ/RFP. ${ }^{92}$ The REOI also serves to attract interest in the competition and inform potential bidders about key aspects of the competition. It is a non-binding, discretionary stage that may not be employed in every competition. ${ }^{93}$

The RFQ was issued on 28 April 2017, with a deadline for responses of 16 June $2017 .{ }^{94}$ The RFP is anticipated to be issued on 15 September 2017, with a deadline for submissions in response of 13 October 2017. Selection of successful bidders and execution of RESAs are scheduled for December 2017. ${ }^{95}$

\section{IDENTIFYING ELIGIBLE PROJECTS}

At the RFQ stage, the AESO will identify participants eligible to participate in the RFP. The key eligibility criteria set out in the RFQ are as follows:

- $\quad$ projects must be new or expanded development with between $5 \mathrm{MW}$ and $400 \mathrm{MW}$ capacity, located in Alberta, as a single, separately metered facility, with a design life at least equal to the 20 year term of the RESA; ${ }^{96}$

- they must use "an energy resource that occurs naturally and that can be replenished or renewed within a human lifespan, including: (1) Moving Water, (2) wind, (3) heat from the earth, (4) sunlight, and (5) Sustainable Biomass"; 97

- $\quad$ they must be able to connect to the existing AIES (without requiring it to be expanded to accommodate their full capacity under normal conditions) ${ }^{98}$ and

- they must have secured appropriate land rights over their proposed site (lease, option, and others) and be reasonably expected to attain commercial operation by the deadline set in the RESA for them to do so (see further below). ${ }^{99}$

In addition, bidders must demonstrate:

- That they satisfy requirements of financial strength and capability, including that they have secured commitment for 51 percent of the equity required for the project from equity providers who have sufficient Tangible Net Worth (as defined, at some length, in the RFQ) relative to the proposed project size (at least $\$ 250,000$ per MW

\section{Ibid, s 1.1 .}

The AESO recommended that this stage would not be required for each competition.

Request for Qualifications for the First Renewable Electricity Program Competition: REP Round 1 (28 April 2017), online: $<$ https://www.aeso.ca/assets/Uploads/ Request-for-Qualifications-for-REP-Round1.pdf> [RFQ]; Alberta Electric System Operator, Draft Renewable Electricity Support Agreement: Renewable Electricity Program, Round 1 (28 April 2017), online: $<$ https://www.aeso.ca/assets/Uploads/ Draft-RESA.pdf $>$ [Draft RESA]. For REP Round 1 documents generally, see online: AESO $<$ https:// www.aeso.ca/market/renewable-electricity-program/rep-news-and-updates/>. REOI, supra note 91 at 4.

RFQ, supra note 94, Part B, s 3.1(a), (d), (j).

Ibid, Appendix A ("Moving Water," "Renewable Fuel," and "Sustainable Biomass").

Ibid, Part B, s 3.1(h).

Ibid, Part B, s 3.3. 
of proposed capacity); any sponsor or guarantor must confirm their willingness to provide support. ${ }^{100}$

- Their technical capacity and capability to develop their proposed projects, as evidenced by their involvement in recent projects of similar size and complexity, experience with project development, construction, and operation, and the relevance of the participant's experience to the proposed project. ${ }^{101}$

The RFQ is a binding, required stage in the process that is expected to be the most resource-intensive for both the AESO and participants, who must pay a non-refundable fee to participate. $^{102}$

The RFP is the final stage, and is only open to participants who qualified at the RFQ. The RFP is intended to be a pricing stage whereby qualified participants will be evaluated on price. Participants will be required to confirm that they remain qualified, and to provide a final offer and post security.

The AESO considers that an in-service date of 2019 is "likely achievable" for projects collectively representing more than $1,500 \mathrm{MW}$ of new or expanded renewable generation. ${ }^{103}$ Depending on the financial and technical robustness of the teams behind these projects, this suggests that potentially more than three times the maximum quantity of government supported renewable generating capacity could be eligible to compete in Round 1.

\section{QUANTIFyING THE AVAILABILITY OF SUPPORT}

At the time of writing, only limited detail about the RFP process was available. However, the Alberta government has determined that in Round 1 of the REP, projects using different technologies will compete against each other - what is sometimes referred to as a fuel neutral or technologically neutral approach. ${ }^{104}$ Developers will bid to secure a share of the total $400 \mathrm{MW}$ of renewable generating capacity the government has conditionally committed to support under the first batch of RESAs. The commitment is conditional in the sense that the government has established an affordability threshold in terms of the amount of money it is prepared to pay out under the first batch of RESAs. If that threshold would be exceeded by $400 \mathrm{MW}$ of successful capacity, less than $400 \mathrm{MW}$ of RESAs may be awarded. Equally, there is discretion to exceed the affordability threshold. updates/> [AESO, "Details"].

101 AESO, REP Recommendations, supra note 55 at 15.

$102 \$ 1,000$ per MW, for a minimum of $\$ 10,000$ and up to a maximum of $\$ 50,000$, plus $\$ 2,500$ for each additional project submitted in addition to the first (see AESO, "Details," supra note 100). 


\section{RENEWABLE ELECTRICITY SUPPORT AgREEMENTS}

The AESO has estimated that between two and six years are required to develop, permit, and energize a project. ${ }^{105}$ It is expected that the projects awarded RESAs in Round 1 with a view to their coming into service by December 2019 will already be well advanced. RESAs will have a duration of 20 years.

\section{B. INTERNATIONAL COMPARATORS}

\section{GREAT BRITAIN}

Like Alberta, Great Britain has had an energy-only electricity market for many years. In Great Britain, both the generation and supply of power are fully open to competition. When the industry was privatized in 1990, the wholesale market had a pool structure similar to that of Alberta, but for the last 16 years, the wholesale market has been based entirely around bilateral contracts between generators, suppliers, and financial traders. Market reference wholesale prices emerge on power exchanges, rather than as a result of a process organized by the system operator, National Grid. However, National Grid is responsible for the balancing market in which generators and suppliers make bids and offers of the prices they are prepared to accept from the system operator, in exchange for altering their behaviour in any of the half-hour settlement periods into which each day is divided. ${ }^{106}$

Like Alberta, the United Kingdom now has targets for increasing the share of renewable energy ( 30 percent of all final energy by $2020^{107}$ ) and reducing greenhouse gas emissions (by 80 percent against a 1990 baseline $^{108}$ ). However, the Renewables Obligation (RO), the first (and so far most important) ${ }^{109}$ British renewable support regime predates these targets. It was introduced in 2002 and is a green certificate and RPS scheme. Under the RO, at the end of each 12 month compliance period, each utility (supplier) must surrender to the regulator, Ofgem, a certain number of Renewable Obligation Certificates (ROCs) based on its market

AESO, REP Recommendations, supra note 55 at 25.

Market operators must notify National Grid of their intended import from or export to the grid in each settlement period (which will be the subject of bilateral commercial contracts). If National Grid calculates that these will lead to imbalances between supply and demand (with potentially adverse consequences for system frequency and, ultimately, security of supply), it may accept a generator's offer to decrease its export to the grid or a supplier's offer to decrease its import from the grid. For further detail, see ELEXON, "The Electricity Trading Arrangements: A Beginner's Guide” (5 November 2015), online: $<$ https://www.elexon.co.uk/wp-content/uploads/2015/10/beginners_guide_to_trading_arrange ments_v5.0.pdf>.

EC, Commission Directive 2009/28/EC of 23 April 2009 on the promotion of the use of energy from renewable sources and amending and subsequently repealing Directives 2001/77/EC and 2003/30/EC, [2009] OJ, L 140/16, online: <eur-lex.europa.eu/legal-content/EN/TXT/PDF/?uri=CELEX:32009L0028 \&from $=\mathrm{en}>$.

Climate Change Act 2008 (UK), c 27. See also the website of the Committee on Climate Change, the UK Government's statutory advisor on Climate Change Act matters in particular: online: <https://www. theccc.org.uk/about/>.

In 2009, Great Britain decided to adopt a system of FiTs to complement the existing RO regime. The FiTs regime, which is outside the scope of this article, was aimed primarily at very small-scale, domestic installations, but the upper limit on projects eligible to participate in it (5 MW) was set high enough to allow it to be exploited by commercial developers of stand-alone, utility-scale projects: UK Government, Department of Energy and Climate Change, Feed-in Tariffs: Government's Response to the Summer 2009 Consultation (February 2010), online: <www.fitariffs.co.uk/library/regulation/100201Final Design.pdf $>$. 
share. For each ROC a supplier fails to provide, it must pay a buyout price prescribed in the legislation. ${ }^{110}$

The government aims to set the level of suppliers' obligations so that it matches the number of ROCs that will be issued to generators of renewable electricity. Although ROCs are freely traded, their market value generally tends to be fairly close to the level at which the buyout price is set. In the long-term PPAs that the existence of the RO incentivizes suppliers to enter into with generators, the price suppliers pay for ROCs tends to be set by reference to the buyout price (for example, 95 percent of the buyout price).

In broad terms, the RO makes the purchase of a MWh of renewable power more than twice as expensive as it would be if the supplier only had to pay the prevailing wholesale market price. ${ }^{111}$ This, coupled with the fact that the RO contained no means of capping the amount of new generation that could be accredited to receive ROCs in any given compliance period, gave rise to concerns about the costs of the scheme and the burdens it imposed on end-users of power, on whom the costs imposed on suppliers ultimately fell. ${ }^{112}$

The government decided to replace the RO with a CFD regime. ${ }^{113}$ This happened as part of a program known Electricity Market Reform (EMR), developed and put in place between 2010 and $2014 .{ }^{114}$ Key features of the EMR architecture are:

See the multiple resources in Ofgem, "About the RO," online: <https://www.ofgem.gov.uk/environ mental-programmes/ro/about-ro>.

111 Many projects receive more than $1 \mathrm{ROC} / \mathrm{MWh}$, and current average per MWh wholesale prices are below the ROC buyout price (Ofgem figures show average day-ahead baseload wholesale contract prices for the first 6 months of 2017 of $£ 44.14 / \mathrm{MWh}$, whilst the ROC buyout price was $£ 44.77$ (until 31 March 2017) or £45.58 (from 1 April 2017): see Ofgem, "Electricity Prices: Day-Ahead Baseload Contracts - Monthly Average (GB)" (October 2017), online: <https://www.ofgem.gov.uk/data-portal/electricityprices-day-ahead-baseload-contracts-monthly-average-gb> [Ofgem, "Day-Ahead Baseload Contracts"]; Ofgem, "Renewables Obligation (RO) Buy-Out Price and Mutualisation Ceilings for 2017-18" (24 February 2017), online: $<$ https://www.ofgem.gov.uk/publications-and-updates/renewables-obligation-robuy-out-price-and-mutualisation-ceilings-2017-18>). In 2009, the RO regime was reformed so as to allow differing numbers of ROCs to be awarded per MWh of electricity generated by different technologies. Those technologies considered to be more in need of financial assistance to develop to their full potential would be given a higher "ROC banding" than those that were already wellestablished. If it was predicted that over a period of several years, a given technology's set-up costs would decrease to an extent that could be sensibly estimated, it would be provided that the number of ROCs awarded per MWh of power generated from projects that began to export power to the grid in a later year would be smaller than the number awarded to projects that began to export in the current year. For details of the policy process leading up to the 2009 reforms, see UK Government, Department for Business, Enterprise \& Regulatory Reform, "Renewables Obligation" (12 December 2008), online: The National Archives < webarchive.nationalarchives.gov.uk/20081212112146/http://www.berr.gov.uk/what wedo/energy/sources/renewables/policy/renewables-obligation/page15630.html $>$. For banding levels in recent years, see UK Government, "Renewable Obligation Banding Levels: 2013-17," online: $<$ https:// www.gov.uk/government/uploads/system/uploads/attachment data/file/211292/ro banding levels_2013_17.pdf>, < https://www.gov.uk/guidance/calculating-renew able-obligation-certificatesrocs $>$.

112 This led to the creation of an attempt to limit overall renewable subsidy expenditure, known as the Levy Control Framework: see National Audit Office, "The Levy Control Framework" (27 November 2013), online: <https://www.nao.org.uk/report/levy-control-framework-2/>; National Audit Office, "LowCarbon Electricity Supported by the Levy Control Framework" (November 2016), online: $<$ https://www. nao.org.uk/wp-content/uploads/2016/10/Low-carbon-electricity-supported-by-the-levy-controlframework.pdf>.

For full historic policy documentation, see UK Government, "Electricity Market Reform: Contracts for Difference" (2017), online: <https://www.gov.uk/government/collections/electricity-market-reformcontracts-for-difference>.

114 The primary legislation for EMR was the Energy Act 2013 (UK), c 32, under the relevant provisions of which numerous sets of Regulations and Rules have subsequently been made. Key milestones in the policy development process included: UK Government, Planning Our Electric Future: A White Paper for Secure, Affordable and Low-Carbon Electricity (July 2011), online: <https://www.gov.uk/govern 
- A market-wide, central buyer capacity mechanism that rewards all providers of electricity capacity who are successful in a competitive auction process with an additional source of revenue in the form of capacity payments, if they are available to provide their contracted capacity when National Grid calls on them to do so the Capacity Market. ${ }^{115}$

- An additional tax on coal and gas used as fuel in power stations (the carbon price support mechanism). ${ }^{116}$

- The phasing out of the RO and its replacement by the CFD regime. ${ }^{117}$

The RO regime automatically provides each accredited project with the number of ROCs per MWh prescribed for the technology it uses. It prescribes a compliant completion period, with no overall financial constraint imposed. In contrast, CFDs are awarded to projects that have not yet been built, and are carefully rationed through the CFD allocation round process.

The allocation round has two stages. The first, pre-qualification, determines which projects meet the eligibility criteria.

- $\quad$ Projects must use one of the technologies listed as eligible for CFD support in the relevant legislation. However, since there is no obligation on the government to hold an auction that is open to all the eligible technologies, they must also use a technology that is covered by the particular auction for which they are seeking prequalification. For example, the 2017 auction does not include solar photovoltaic (PV) or onshore wind. ${ }^{118}$

- A qualifying project must show that it has all the development consents that may be required from public authorities in order to allow the construction of (1) the generating station itself; and (2) any connection infrastructure necessary to allow the power it produces to be exported to a public transmission or distribution grid, or a private network. It must also show that agreement has been reached on a connection with any transmission or distribution network operator into whose network the project is proposed to connect. ${ }^{119}$

- $\quad$ Projects with a capacity of $300 \mathrm{MW}$ face a further pre-qualification hurdle in that they must include, in their pre-qualification applications, a plan showing how they

ment/publications/planning-our-electric-future-a-white-paper-for-secure-affordable-and-low-carbonenergy>; UK Government, Implementing Electricity Market Reform (EMR) (2014), online: <https:// www.gov.uk/government/publications/implementing-electricity-market-reform-emr $>$ [UK Government, Implementing EMR].

115 For an outline of the Capacity Market policy, see UK Government, Implementing EMR, ibid. On the auction process, see National Grid, "Capacity Market Auction User Guide: Guidance Document for Capacity Market Participants,” online: <https://www.emrdeliverybody.com/Lists/Latest\%20News/ Attachments/92/Capacity\%20Market\%20Auction\%20User\%20Guide\%20v3.pdf>.

116 UK Government, "Excise Notice CCL1/6: A Guide to Carbon Price Floor,"s 2.2, online: <https://www. gov.uk/Government/publications/excise-notice-ccl16-a-guide-to-carbon-price-floor/>.

117 Multiple resources at UK Government, "Contracts for Difference" (2017), online: < https://www.gov.uk/ government/publications/contracts-for-difference/contract-for-difference $>$.

118 UK Government, Implementing EMR, supra note 114, s 2.2.3.1.

119 Ibid. 
will contribute to the development of supply chains approved by the government. ${ }^{120}$ Any project whose plan has not been so approved is therefore ineligible to apply for a CFD. The overall objective is to demonstrate that the project makes a material contribution to the economic growth and viability of the industrial supply chain supporting the low carbon electricity generation sector.

Once projects have been screened for eligibility, the second stage, the allocation process proper, takes place. For each allocation round, a series of budgets sets out the maximum amounts of support to be awarded. This has so far been done by reference to (1) the estimated subsidy costs of each project over the 15 year term of a CFD; (2) the delivery year in which the developer expects a project to be completed; and (3) sub-groups of eligible technologies known as Pots. ${ }^{121}$ The budget for the 2017 auction is reproduced below.

TABLE 4:

STATUTORY CFD BUDGeT NOTICE, 13 MARCH $2017^{122}$

\begin{tabular}{|l|c|c|}
\cline { 2 - 3 } \multicolumn{1}{c|}{} & \multicolumn{2}{c|}{ Delivery Year } \\
\hline £ million (2011/12 prices) & $2021 / 22$ & $2022 / 23$ \\
\hline $\begin{array}{l}\text { Overall budget to be allocated to Pot 2 (less } \\
\text { established technologies*) }\end{array}$ & 290 & 290 \\
\hline
\end{tabular}

* These technologies are offshore wind, advanced conversion technologies (with or without combined heat and power (CHP)), anaerobic digestion (with or without CHP), dedicated biomass with CHP, wave, tidal stream, and geothermal (with or without CHP).

Each project is valued by multiplying the difference between the relevant strike price and a notional market reference price (giving a per MWh subsidy cost) by the project's generating capacity, anticipated load factor, the number of hours in the day, and adjustments for technical factors such as transmission line losses. The result is an estimate of the project's costs over the 15 year term of the CFD. ${ }^{123}$

To begin with, the valuation process is carried out using the technology-specific administrative strike prices which are set by the government as caps on the amount that a project of a given technology can be awarded as a strike price. If the total subsidy cost of projects competing to deliver in a given year calculated in this way is no more than the budget for that year, all the projects are awarded a CFD at the administrative strike price.

UK Government, Department for Business, Energy \& Industrial Strategy, "Accompanying Note to the Budget Notice for the Second CFD Allocation Round" (13 March 2017), online: <https://www.gov.uk/ government/uploads/system/uploads/attachment_data/file/598813/Accompanying_note_for_Final_ Budget_Notice_Second_Round_2_.pdf $>$.

UK Government, "Second CFD Allocation Round - Statutory Notices" (13 March 2017), online: $<$ https://www.gov.uk/government/publications/second-cfd-allocation-round-statutory-notices> [UK Government, "Second Round Budget Notice"].

123 UK Government, Contracts for Difference: Allocation Framework for the Second Allocation Round (March 2017) at Schedule 2, online: <https://www.gov.uk/government/uploads/system/uploads/ attachment_data/file/601120/Allocation_Framework_for_the_second_Allocation_Round.pdf $>$ [Allocation Framework]. 
However, if (as will invariably be the case) the total subsidy cost of pre-qualified projects is greater than the budget, a competitive auction takes place.

In the auction, projects are ranked in ascending order of the strike prices submitted in sealed bids by their developers, and stacked until the total costs of the stack of projects reaches the budget set for the allocation round. All the projects that fit within the budget for a given delivery year on this basis are then awarded CFDs with a strike price equal to that of the last project to fit within the budget (that is, the one with the highest strike price). This becomes the clearing price of the auction for that delivery year. ${ }^{124}$

Once awarded, a CFD can be terminated if the generator (1) fails to meet a set of preconstruction milestone requirements (usually within one year of signing), ${ }^{125}$ or (2) fails to construct at least the majority (typically 95 percent, but 85 percent for offshore wind) of the project's capacity by a specified longstop date (usually one or two years after the end of the specified Target Commissioning Window (TCW), during which construction is expected to be completed). ${ }^{126}$ Even if a CFD is not terminated, failure to complete construction before the end of the TCW results in a loss of revenue for the generator, because the contract's payment provisions expire 15 years at the latest from the start date, whether any power (and any resulting entitlement to CFD payments) is being generated at that date or not. ${ }^{127}$

Three more points are worth noting by way of background about the CFD regime.

- The CFD regime is intended to provide the basis for subsidizing not just renewables, but also other forms of low carbon generation, notably new nuclear generating capacity, and potentially also new fossil-fuel generation fitted with CCS technology. ${ }^{128}$ This meant that the standard terms of CFDs were, to a material extent, a reflection of negotiations between the government and EDF as the

This is a very simplified description of the auction process, which has a number of additional layers: see the Allocation Framework, ibid for details.

125 All consents must be in place with evidence of committed funding within a year of the CFD being signed. Each CFD is comprised of a short "CFD Agreement," online: <https://www.gov.uk/government/ uploads/system/uploads/attachment_data/file/492816/CfD_Agreement Generic _with_footnotes_26 October 2015.pdf $>$ [CFD Agreement] and a much longer set of "FiT Contract for Difference Standard Terms and Conditions," online: $<$ https://www.gov.uk/government/uploads/system/uploads/ attachment_data/file/492815/CfD___Standard_Conditions_-26_October_2015.pdf> [CFD Standard Terms]. See UK Government, Contracts for Difference: - Standard Terms and Conditions, online: $<\mathrm{https}$ ://www.gov.uk/government/publications/contracts-for-difference-standard-terms-and-conditionsdecember-2015-update>. On the Milestone Requirements, see CFD Standard Terms, s 4.1, read with Annex 5 to the CFD Agreement.

126 CFD Standard Terms, ibid, s 53.1(D), read with s 7.2 of the CFD Agreement, ibid.

127 The period during which CFD payments can be received will be shortened by the number of days by which the notified Start Date, when commercial operation begins, is later than that date. The generator has the ability to extend the TCW or the longstop period if the network operator has failed to carry out necessary connection or reinforcement works, or by invoking the CFD's force majeure provisions. However, the definition of force majeure in the CFD is relatively narrow, being essentially confined to legislative or regulatory action (for example, refusal to grant a permit required to operate the project). CFD Standard Terms, ibid, ss 1 ("Longstop Date"), 2.1(B), 3.21.

128 The allocation of CFDs to nuclear, CCS and certain classes of large-scale first-of-a-kind renewable projects (such as tidal lagoons) are not subject to the competitive auction process described here: regarding CCS and nuclear, see Contracts for Difference (Allocation) Regulations 2014, SI 2014/2011, s 14(2); regarding tidal lagoons, the British government commissioned an independent review on various aspects of this technology, including their suitability or otherwise for being subject to a competitive CFD allocation mechanism - see Charles Hendry, The Role of Tidal Lagoons: Final Report (December 2016), online: Hendry Review <https://hendryreview.files.wordpress.com/2016/08/hendry-review-finalreport-english-version.pdf $>$. 
developer of the Hinkley Point $\mathrm{C}$ new nuclear power station. Drafting designed for a $3 \mathrm{GW}$ nuclear plant is arguably a bit over-engineered for a $10 \mathrm{MW}$ solar or onshore wind project. ${ }^{129}$

- The move from a regime where subsidies were awarded ex post to one where they were awarded ex ante meant that if the RO was closed to new projects at the same time as CFDs were first allocated, there would be a hiatus in the pipeline of renewable generation projects being built (except perhaps in the case of solar projects, whose development cycle is measured in months rather than years). To avoid this, the British government decided to allow a period of transition between the RO and CFD regimes. The length of this period was effectively determined by the needs of the technologies with the long development cycles. In other words, the period was set to accommodate developers who had incurred significant expense with a view to achieving RO accreditation at a certain number of ROCs/MWh in 2017.

- $\quad$ Responsibility for administering the CFD regime is split between three different bodies. The Department of Business, Energy and Industrial Strategy (BEIS, formerly the Department of Energy and Climate Change) is responsible for determining when allocation rounds take place, the size of the budget for each allocation round, which technologies are permitted to compete in it, and what the allocation rules will be. The pre-qualification and allocation processes are essentially administered by a ring-fenced division of the System Operator, National Grid. The CFDs themselves are entered into between the generator and the Low Carbon Contracts Company (LCCC), ${ }^{130}$ a government-owned, bankruptcy-remote entity that administers the contracts. The LCCC makes and receives CFD payments owed to or by generators. Payments to generators are funded by a levy on suppliers. ${ }^{131}$ BEIS has wide discretion with respect to setting the terms of allocation rounds: ministers are not subject to any parliamentary control in this regard. National Grid and the LCCC generally enjoy only very limited discretion, except, for example, in the LCCC's case, with respect to decisions to terminate a CFD for failure to meet milestones.

One legacy of Hinkley on the standard CFD terms is that the change in law provisions are very long, and only allow a change in law to give rise to a change in the strike price in very narrow circumstances. The corresponding provisions of the draft RESA are brief and permissive by comparison: see CFD Standard Terms, supra note 125, Part 8; Draft RESA, supra note 94, art 11.

130 The LCCC's website is online: <https://lowcarboncontracts.uk/>.

131 See the Contracts for Difference (Electricity Supplier Obligations) Regulations 2014, SI 2014/2014; CFD Standard Terms, supra note 125, Part 6, ss 71.1-71.8. 


\section{GERMANY}

When it comes to renewable energy, there is no doubting either Germany's achievements or its ambition. Already, some 32 percent of electricity supplied in Germany comes from renewable sources. ${ }^{132}$ Germany's goal is to raise that proportion to $40-45$ percent by 2025 , and 55-60 percent by $2035 .{ }^{133}$

The German Renewable Energy Sources Act ${ }^{134}$ (Erneuerbare Energien Gesetz or EEG) originally offered guaranteed FiTs for all renewable generation. Since 2012, this system has been progressively replaced by a floating market premium model. From then on, operators had the option to sell electricity directly on the wholesale market while receiving the difference between the applicable reference price and the average price for electricity on the spot market of the German electricity exchange (market premium). With the EEG in 2014, an element of competition was successfully introduced into determining the level of the market premium. Starting with commercial scale solar power plants, the auction model was applied to determine the level of the premium. ${ }^{135}$

With the revised EEG of 2017, renewable generation plants with a capacity of $750 \mathrm{~kW}$ or more for wind and solar powered generation, or $150 \mathrm{~kW}$ for biomass powered generation, can only receive subsidized energy prices after a tender process. ${ }^{136}$ Facilities with a lower capacity may still be eligible for FiTs. In this tender process, a certain generation capacity in MWs is tendered by the Federal Network Agency (Bundesnetzagentur or BNetzA). Bidders must complete a pre-qualification procedure in advance. This procedure serves to verify, among other things, whether the bidder is going to realize the proposed project if it wins. The bidders have to provide bank guarantees or cash deposits in the amount of 30 to 60 EUR per kW of proposed capacity, depending on the energy source. These securities are refunded if the bidder is unsuccessful. ${ }^{137}$

BMWi, "Development of Renewable Energy Sources in Germany 2016," online: <www.erneuerbareenergien.de/EE/Redaktion/DE/Downloads/entwicklung_der_erneuerbaren energien in deutschland_im jahr_2016.pdf? blob=publicationFile\&v=16 $>$; German Federal Environmental Agency (Umwelt Bundesamt), "Renewable Energies — the Figures" (2016), online: UB <www.umwelt bundesamt.de/en/topics/climate-energy/renewable-energies/renewable-energies-the-figures>. German Federal Government Press and Information Office, "Energy Revolution" (2017), online: $<$ https://www.bundesregierung.de/Content/DE/StatischeSeiten/Breg/Energiekonzept/0-Buehne/ ma\%C3\%9Fnahmen-im-ueberblick.html>.

Erneuerbare-Energien-Gesetz (17 July 2017), online: < https://www.gesetze-im-internet.de/eeg_2014/ BJNR106610014.html > [EEG 2017].

135 The most detailed publicly available account of the new EEG arrangements available in English is probably to be found in the European Commission's decision in case SA.45461 (see online: $<$ ec.europa.eu/competition/state aid/cases/264992/264992 1871004 175 2.pdf $>$ ), granting clearance under EU state aid rules. There are useful summaries in German in Franz-Josef Kemnade \& Christian Sperling, "Die Ausschreibung: Unsere Serie zum EEG 2017" (5 October 2016), NEXT Kraftwerke (blog), online: <https://www.next-kraftwerke.de/energie-blog/eeg-2017-ausschreibungen $>$ and in the BMWi fact sheets relating to the EEG 2017, online: <https://www.bmwi.de/Redaktion/DE/Publik ationen/Energie/fit-fuer-den-strommarkt.pdf?__blob=publicationFile \&v=29>, $<$ https://www.bmwi.de/ Redaktion/DE/Downloads/E/eeg-2017-fragen-und-antworten.pdf?_blob=publicationFile\&v=14>. Due to the high investment costs and long planning procedures for offshore wind farms, between 2021 and 2025, only wind farms that have been permitted before August 2016 will be eligible to participate in the tender: see BNetzA, "Windenergieanlagen auf See" (2017), online: BnetzA <https://www. bundesnetzagentur.de/DE/Sachgebiete/ElektrizitaetundGas/Unternehmen_Institutionen/Erneuerbare Energien/Offshore/offshore-node.html>.

137 Windenergie-auf-See-Gesetz (20 July 2017), §25, online: <www.gesetze-im-internet.de/windseeg/BJNR 231000016 .html $>$ (offshore wind turbines); EEG 2017, supra note 134, § 55a (other renewables). 
The bidders offer a price per kWh (bid price). In order to prevent abuse and price fixing, a technology specific maximum bid price is specified by the BNetzA beforehand. The bids are accepted from lowest to highest, until the whole tendered capacity is awarded. Each successful bidder is guaranteed the price it offered for a period of 20 years (a "pay as bid" procedure), ${ }^{138}$ and a grid connection at no cost. In return, the successful bidder is obliged to market the electricity directly on the wholesale energy market. Rather than receiving the full bid price as a fixed tariff from the grid operator, a successful bidder receives the difference between its bid and the average monthly price on the spot market of the German electricity exchange as a market premium, and is expected to achieve its remaining revenue on the energy market. The market premium determined in this way is paid by the transmission grid operator (TSO) which, in turn, is entitled to charge this premium on to the energy suppliers that then add the respective surcharge on the electricity bill of the individual electricity consumer. As the market premium is flexible depending on the average monthly wholesale price, bidders are required to anticipate the monthly wholesale price for electricity. Thus, if a bidder anticipates an average monthly price of 4 cents $/ \mathrm{kWh}$, it may decide that at that price it would need an additional 4 cents/kWh for its project to make an acceptable return, so it would bid a reference value of 8 cents $/ \mathrm{kWh}$. If its bid was successful, in any month when the average monthly price was in fact 3.5 cents $/ \mathrm{kWh}$, it would receive a payment of 4.5 cents $/ \mathrm{kWh}$ from the TSO. If the average monthly price was $4.5 \mathrm{cents} / \mathrm{kWh}$, it would receive a payment of 3.5 cents $/ \mathrm{kWh}$. If the average monthly price was 8 cents $/ \mathrm{kWh}$ or above, it would not receive payment from the TSO, but it would benefit from the increased market price. In general, the proportion of the bid price that is subsidized varies according to market prices (a floating market premium). Successful bidders receive a total revenue of the reference value they have bid as a minimum. However, they can achieve larger revenues when beating the average wholesale price in any month.

The bidding process aims to reduce the price for electricity from renewable sources, and to increase the efficiency of renewables by promoting competition between operators. ${ }^{139}$ Failure to complete a project which has won an auction within a set period, results in the cancellation of the awarded bid and the imposition of penalties (deducted from the security provided).

\section{UNITED STATES}

The US is a complex jurisdiction for energy regulation. There is not simply one jurisdiction in the US, there are 53 separate jurisdictions - the federal government, the 50 state governments, the District of Columbia, and the city of New Orleans, Louisiana - plus all of the US Territories. In addition, the US has seven regional transmission organizations (RTOs), four of which span regions incorporating multiple states. Adding to the regulatory complexity, the lack of a comprehensive federal policy on issues like an RPS, and the general gridlock in Congress over the last several years, has led state governments to enact their own, differing policies designed to encourage investment in desirable resources, often driven by (such as the UK CFD regime), each project gets the strike price of the successful bidder with the highest strike price.

139 BMWi, "Fragen und Antworten zum EEG 2017,", online: $<$ https://www.bmwi.de/Redaktion/DE/Down loads/E/eeg-2017-fragen-und-antworten.pdf? _ blob=publicationFile\&v=14> [BMWi Q\&A]. 
environmental concerns. Further, because states do not have the jurisdiction to regulate the markets, most attempts by the states to determine where and what type of capacity is built have occurred through out-of-market measures, such as renewable portfolio standards, energy efficiency resource standards, integrated resource planning proceedings, state tax incentives, and the like.

There is a considerable amount of variation in the methods chosen by the states, and there is currently an extensive amount of dialogue occurring in the US as to whether state policy goals should be accomplished through the Federal Energy Regulatory Commission's (FERC) adjustment of market rules, outside of the market structure, or if there should be some structure in between those two extremes. FERC held a Technical Conference on 1-2 May 2017 on the impact of state policies on wholesale markets in New England, New York, and PJM. ${ }^{140}$ The RTOs and RTO market monitors asserted that state policies encouraging renewables, particularly through a requirement that utilities procure renewables or a subsidy of renewables, can lead to an artificial surplus of capacity. ${ }^{141}$ The market monitor argued that trying to achieve state renewables goals through RTO markets will cause them to cease to be effective in facilitating resource adequacy, and noted that carbon pricing would be a recommended fix for this problem, but that it is unpopular. ${ }^{142}$ As an alternative, the market monitor and ISO-NE proposed a new two-stage capacity auction mechanism that would explicitly coordinate entry of new resources with retirement of old resources. ${ }^{143}$ Similarly, PJM proposed two possible two-stage auction mechanisms to relieve the potential for surplus capacity. ${ }^{144}$ Meanwhile, generators argued that all solutions should be market-driven (such as carbon pricing) and state policies should observe the jurisdictional limits of the states. ${ }^{145}$ Municipally-owned utilities argued that the centralized capacity markets in the East do not address the energy-related goals of states or consumers, including environmental goals, and that those goals would be better served by making changes to the rules to promote bilateral contracting and reduce the role of the capacity markets. ${ }^{146}$ State advocates urged FERC to

US, FERC, Notice of Technical Conference (FERC Doc No AD17-11-000) (3 March 2017) at 1. FERC writes:

Because the wholesale competitive markets, as currently designed, select resources based on principles of operational and economic efficiency without specific regard to resource type, there is an open question of how the competitive wholesale markets, particularly in states or regions that restructured their retail electricity service, can select resources of interest to state policy makers while preserving the benefits of regional markets and economic resource selection.

For discussion of some of the recent cases that have highlighted concerns in this area, see the section on US capacity markets, below.

US, FERC, Comments of David B Patton, PhD Regarding State Policies Affecting Eastern RTOs (FERC Doc No AD17-11-000) (24 April 2017) at 3-4 [Patton Comments]; US, FERC, ISO New England Inc Pre-Technical Conference Statement (FERC Doc No AD17-11-000) (3 May 2017) at 1-2 [ISO-NE Statement].

142 Patton Comments, ibid at 5-6.

143 Ibid; ISO-NE Statement, supra note 141 at 3-4.

PJM Interconnection LLC, "Capacity Market Repricing Proposal" (2 May 2017), online: <pjm.com/ / media/library/reports-notices/special-reports/20170502-capacity-market-repricing-proposal.ashx>. US, FERC, Comments of Independent Power Producers of New York, Inc (FERC Doc No AD17-11000) (28 April 2017) at 8; US, FERC, Technical Conference Opening Statement of John E Shelk, President \& CEO, Electric Power Supply Association (FERC Doc No AD17-11-000) (25 April 2017) at 8 .

146 US, FERC, Pre-Conference Statement of Lisa G McAlister on Behalf of American Municipal Power, Inc (FERC Doc No AD17-11-000) (25 April 2017) at 4-5; US, FERC, Written Comments of Brian Forshaw (FERC Doc No AD17-11-000) (1 May 2017) at 3-5. See also Jeannine Anderson, "Changes Needed in Centralized RTO Markets, Public Power Utilities Say," Public Power Daily (11 May 2017), online: American Public Power Association <www.publicpower.org/Media/daily/ArticleDetail.cfm?Item Number $=48088>$. 
work with them to achieve their policies, and consumer advocates cautioned against actions that impede the ability of the markets to provide customers with the lowest possible price. ${ }^{147}$

There is also recent case law indicating that FERC may be able to adjust wholesale market rules in a manner that impacts the states' policy goals. In Federal Energy Regulatory Commission v. Electric Power Supply Association, which was decided by the US Supreme Court in January 2016, the Court found that FERC had the authority to require wholesale electric market operators to pay the same price to demand response providers for conserving energy (that is, for demand-side management resources) as to generators for producing energy, so long as consumers actually saved money, since the rule directly affected the wholesale rate, which was reduced by displacing higher-priced generation bids. The Supreme Court overturned a Court of Appeals decision which had found that FERC did not have authority to regulate demand-side management resources, since they were strictly a retail service that fell under the jurisdiction of state regulators. The Supreme Court found that although the transactions occurring on the wholesale market affected retail rates, it did not invade the states' authority to regulate retail rates since every aspect of the plan happened exclusively on the wholesale market and was governed exclusively by the wholesale market's rules. ${ }^{148}$

While a number of approaches are used by the states to encourage investment in renewable generation, the CFD model is not currently available to the states to the extent that it would effectively alter wholesale market prices. A recent effort by the state of Maryland to put a CFD into place, to provide an incentive for a generator to locate in a constrained area of the state, was overturned by the US Supreme Court in Hughes v. Talen Energy Marketing, LLC. ${ }^{149}$

Under the Federal Power Act, ${ }^{150}$ FERC has exclusive authority to regulate the sale of electric energy at wholesale in interstate commerce, and states may not regulate wholesale rates or markets. However, in the Hughes case, Maryland regulators became concerned that the PJM capacity auction was failing to encourage development of sufficient new in-state generation. Having failed to persuade FERC to adjust its rules, the Maryland Public Service Commission issued a Generation Order soliciting proposals from various companies for construction of a new gas-fired power plant at a particular location, and once they accepted a bid, required all load serving entities in Maryland to enter into a 20 year CFD with the winning bidder at the rate that had been specified in the winning bid. The generator's competitors brought suit arguing that Maryland's program impermissibly set a wholesale rate for electricity and interfered with FERC's capacity auction policies. ${ }^{151}$ The US Supreme Court found that by insulating the generator from market prices, Maryland's program did

Sre-Technical Conference Statement by Janet Joseph, New York State Energy Research and Development Authority (FERC Doc No AD17-11-000) (25 April 2017) at 5; US, FERC, Pre-Conference Comments of the Joint Consumer Advocates (FERC Doc No AD17-11-000) (25 April 2017) at 4. Federal Energy Regulatory Commission v Electric Power Supply Association, 136 S Ct 760 (2016). $136 \mathrm{~S} \mathrm{Ct} 1288$ at 1292 (2016) [Hughes].

Federal Power Act, 16 USC $\S 791$ (a) [FPA]. The FPA is an act passed under the authority granted to Congress in the Commerce Clause of the US Constitution (US Const art I, $\S 8, \mathrm{cl} 3$ ) which gives Congress the power to regulate commerce among the states at 16 USC $\S 824(\mathrm{~b})(1)$.

US Const art VI, cl 2. The Supremacy Clause establishes that the Constitution and federal laws made pursuant to it, or under its authority, are the supreme law of the land, and that state courts are bound by this law. In case of a conflict between federal and state law, the Supremacy Clause requires that the federal law be applied. 
impermissibly set an interstate wholesale rate. The Court wrote "[t]hat Maryland was attempting to encourage construction of new in-state generation does not save its program." 152

The Court in Hughes noted that its holding is limited, writing,

[w]e reject Maryland's program only because it disregards an interstate wholesale rate required by FERC. We therefore need not and do not address the permissibility of various other measures States might employ to encourage development of new or clean generation, including tax incentives, land grants, direct subsidies, construction of state-owned generation facilities, or re-regulation of the energy sector. Nothing in this opinion should be read to foreclose Maryland and other States from encouraging production of new or clean generation through measures "untethered to a generator's wholesale market participation." 153

Thus, Hughes contemplates that a number of measures may be taken by states to encourage new or clean generation, but makes it clear that states may not disrupt the market structures put into place by FERC in order to do so, or tether their programs to a generator's wholesale market prices.

Since it is impossible here to do justice to the diversity of state-level renewable support initiatives, we focus on just one jurisdiction, California, which has a long-established and ambitious renewable energy standard. ${ }^{154}$ California's program relies heavily on the state mandate which "requires investor-owned utilities (IOUs), electric service providers, and community choice aggregators to increase procurement from eligible renewable energy resources to $33 \%$ of total procurement by $2020 . " 155$ As their webpage notes:

The California Public Utilities Commission (CPUC) implements and administers RPS compliance rules for California's retail sellers of electricity, which include investor-owned utilities (IOU), electric service providers (ESP) and community choice aggregators (CCA). The California Energy Commission (CEC) is responsible for the certification of electrical generation facilities as eligible renewable energy resources, and adopting regulations for the enforcement of RPS procurement requirements of Publicly Owned Utilities (POUs). ${ }^{156}$

California's RPS has been relatively successful in encouraging the development of renewable resources. "California's three large IOUs collectively served $27.6 \%$ of their 2015 retail electricity sales with renewable power." 157

Hughes, supra note 149 at 1298.

Ibid at 1299.

California Public Utilities Commission, "California Renewables Portfolio Standard (RPS)," online: $<$ www.cpuc.ca.gov/rps/>. California's RPS was "[e]stablished in 2002 under Senate Bill 1078, accelerated in 2006 under Senate Bill 107 and expanded in 2011 under Senate Bill 2.”

Ibid.

Ibid.

Ibid. 
TABLE 5:

CALIFORNIA'S THREE LARGE IOUS -

Renewable Procurement Status Percentages ${ }^{158}$

\begin{tabular}{|l|c|c|}
\hline \multirow{2}{*}{ Company } & \multicolumn{2}{|c|}{ RPS Procurement (percentage of supply) } \\
\cline { 2 - 3 } & $\mathbf{2 0 1 5}$ (actual) & $\mathbf{2 0 2 0}$ (under contract) \\
\hline Pacific Gas and Electric Company (PG\&E) & $29.5 \%$ & $43.0 \%$ \\
\hline Southern California Edison (SCE) & $24.3 \%$ & $41.4 \%$ \\
\hline San Diego Gas \& Electric Company (SDG\&E) & $35.2 \%$ & $45.2 \%$ \\
\hline
\end{tabular}

The RPS solicitation process is the primary policy framework for the development of utility-scale renewable energy in California. Typically, California's three large [IOUs] issue [annual] solicitations for renewable energy contracts, however, the utilities may also procure renewable energy through all-source solicitations and bilateral contracts. ${ }^{159}$

According to the CPUC, this program was established "for utility procurement of renewable energy to ensure that the utilities meet their RPS obligations through a transparent process. $" 160$

Another procurement program is the Renewable Auction Mechanism or RAM, which "is a simplified market-based procurement mechanism for renewable distributed generation (DG) projects greater than $3 \mathrm{MW}$ and up to $20 \mathrm{MW}$ on the system side of the meter."161 Under the RAM, each utility must develop its own standard RAM contract. ${ }^{162}$

The contracts must contain a few standard terms and conditions: (1) the project must be online within 36 months of contract execution, with one allowable 6-month extension for regulatory delays; (2) the development deposit for projects $5 \mathrm{MW}$ and smaller is $\$ 20 / \mathrm{kW}$, and for projects $5-20 \mathrm{MW}$ it is $\$ 60 / \mathrm{kW}$ or $\$ 90 / \mathrm{kW}$ for intermittent and baseload resources, respectively; ${ }^{163}$ and (3) for projects less than $5 \mathrm{MW}$, the development deposit is converted to the performance deposit, while for projects at least $5 \mathrm{MW}$, the performance deposit is 5 percent of expected total project revenues. ${ }^{164}$

Sellers compete for a contract in a renewable auction mechanism where bids are selected by least-cost price first until the auction capacity is reached, and where the price and contract are not negotiable, but are paid as bid. Each utility may hold as many auctions as needed and specified in the RPS procurement plan. Projects are to be compared against similar product types: baseload, peaking, or intermittent. The projects must be located in the California ISO (CAISO) balancing area or dynamically scheduled into the CAISO to be eligible and must have 100 percent site control through (1) direct ownership; (2) lease; or (3) an option to lease 
or purchase that may be exercised upon award of a RAM contract. ${ }^{165}$ Additionally, to be eligible, the project must be based on commercialized technology, and at least one member of the development team must have (1) completed at least one project of similar technology and capacity; or (2) begun construction of at least one other similar project. The bidder must also have filed an interconnection application. ${ }^{166}$

There are also separate programs for smaller renewables, and the three large IOUs are authorized to own and operate solar facilities as well as to enter into "solar ... power purchase agreements with independent power producers ... through a competitive solicitation process." 167

\section{Lessons LeARNED AND APPLiCATION TO AlbERTA}

\section{INTRODUCING A CFD SCHEME}

The REP has a number of generic similarities with the Great Britain CFD regime and Germany's EEG 2017, but the overarching challenges faced by Alberta are different than those faced in either Great Britain or Germany. For example, in Great Britain and Germany, the task was to replace an established regime that was generally popular with a mature renewables industry, while maintaining a healthy level of renewables deployment and reducing the per MWh costs of subsidy. The Canadian authorities are not replacing an existing regime, and will initially be able to rely on a build-up of existing development stage projects to ensure competition in the bidding process. Beyond the first auction, however, the new regime will need to clearly deliver positive results for all stakeholders in order to maintain momentum for investment in renewable projects. In Alberta, the REP must compare favourably with renewables investment terms available in other jurisdictions, rather than against a pre-existing regime being replaced.

\section{A Regular and PRedictable Pattern of TENDERS}

Businesses, particularly in heavily regulated sectors, value predictability of regulatory action. ${ }^{168}$ One way in which the Great Britain and German regimes contrast is that while the EEG regime specifies the frequency and timing of tenders for each technology and the amount of capacity which will be supported in each tender round, in Great Britain there is no provision in the CFD legislation that obliges BEIS to hold a tender for any technology, ever. $^{169}$

\footnotetext{
165 Ibid.

166 Ibid.

167 RPS Procurement Programs, supra note 159.
}

168 For a critique of UK Government performance in this area, see UK, House of Commons Energy and Climate Change Committee, "Investor Confidence in the UK Energy Sector," Third Report of Session 2015-16 (London: Stationery Office, 3 March 2016), online: <https://www.publications.parliament.uk/ $\mathrm{pa} / \mathrm{cm} 201516 / \mathrm{cmselect} / \mathrm{cmenergy} / 542 / 542 . \mathrm{pdf}>$.

EEG 2017, supra note $134, \S 28$. There is no equivalent provision in the CFD legislation. The National Audit Office, "The Levy Control Framework," supra note 112, has provided some political commitment on overall funding levels, but published policy on the scope and frequency of CFD auctions has shifted considerably. See below and, most recently, the UK Government's announcement of a moratorium on new CFD tenders between 2019 and 2025 (HM Treasury, "Control for Low Carbon Levies" (22 November 2017), online: <https://www.gov.uk/government/publications/control-for-low-carbonlevies $>$ ). 
In order to maintain a healthy project pipeline and strong competition for support in the context of a CFD-type renewable support program, it is important to provide as much certainty as possible about the program over the long term. The British regime has not provided this, and the UK's perceived attractiveness as a destination for investment in new renewable energy generating projects has undoubtedly suffered as a result. The market was originally led to expect that there would probably be, at least, annual allocation rounds for all technologies. So far, there has been one in 2015 (which was actually delayed from 2014) and the 2017 one is ongoing, but it only covers a subset of technologies. ${ }^{170}$ It remains to be seen whether the British government will keep to its promise (given in 2015) to hold a further two auctions by $2020 .^{171}$

Alberta would do much better to follow the German precedent than the British one in this respect, subject to the qualification that if you establish a firm schedule of tenders, the market will lose confidence if it is not adhered to. Within the constraints of the electoral cycle, the authorities in Alberta should establish and live up to clear expectations of what will be on offer, and to which sorts of projects, in future auctions.

\section{EFFECTIVENESS OF COMPETITIVE TENDERING Processes}

The main lesson to be learned from experience in other jurisdictions may be one Alberta already appears to have taken to heart: competitive tendering processes for renewable subsidies can work very well.

As noted above, competitive tendering has been central to the successful Californian approach to meeting the state's renewable electricity standard.

In Germany, the first auctions under the new EEG regime have significantly reduced the cost of subsidy.

- The first tender for onshore wind turbines is in progress. The tender volume of 800 MW was oversubscribed only marginally. This does not imply a high level of competition, which is believed to be due to the fact that many operators scheduled the applications for permits for their plants so as to benefit from the FiT before it ceased to be available. ${ }^{172}$

UK Government, "Second Round Budget Notice," supra note 122.

171 The British CFD program was effectively discontinued for onshore wind because in 2015, the Conservative Party won a general election on a manifesto that included ending new subsidies to onshore wind projects; see The Conservative Party Manifesto 2015 (London: St Ives PLC, 2015), online: $<$ https://s3-eu-west-1.amazonaws.com/manifesto2015/ConservativeManifesto2015.pdf $>$. This led to a lengthy parliamentary struggle to pass provisions of the Energy Act 2016 (UK), c 20, designed to close the RO prematurely to new onshore wind projects, but no change was made to the CFD legislation. For discussion of these struggles, see generally UK Parliament, "Bill Documents - Energy Act 2016," online: <services.parliament.uk/bills/2015-16/energy/documents.html >. Onshore wind remains an eligible technology for CFD purposes, but can be excluded (without any recourse to Parliament) from any given allocation round because ministers have the discretion to determine the contents of the Allocation Framework for a round, and are not subject to any parliamentary control in doing so. Solar has also been excluded from the 2017 auction.

172 Andreas Mihm, "Erneuerbare Energie Lohnt Sich Endlich," Frankfurter Allgemeine Zeitung (13 April 2017), online: $<$ www.faz.net/aktuell/wirtschaft/energiepolitik/windparks-ohne-foerderung-erneuerbareenergie-lohnt-sich-endlich-14971139.html?printPagedArticle=true\#pageIndex_2> [FAZ Article]. 
- One auction for offshore wind turbines with a volume of 1,550 MW has been carried out so far, of which 1,490 MW were allotted. ${ }^{173}$ The winning bids fell well below the currently applicable FiT of 19.4 cents/kWh, ${ }^{174}$ resulting in an average subsidy of only 0.44 cents $/ \mathrm{kWh} .{ }^{175}$ For most of the tender volume, the winning bid amounted to a subsidy of effectively 0.00 cents $/ \mathrm{kWh}$. The average subsidy of 0.44 cents $/ \mathrm{kWh}$ is due to a very small portion of the volume allotted at a subsidy of 0.6 cents/kWh. ${ }^{176}$

Possible reasons for these results are considered below, focusing on the offshore wind auction. ${ }^{177}$

- The low bids can be interpreted as a bet on the assumed increase in electricity prices. Some analysts expect that the electricity price will increase to 5.6 cents $/ \mathrm{kWh}$ in 2025, due to the market exit of coal generation in Germany. Future shutdowns of base load plants, nuclear power plants, and older coal-fired power stations, as well as the increase of the price for greenhouse certificates, are pointed out as the primary causes for this development.

- The auction participants expect that future technological advancements will substantially decrease production costs and maintenance costs for offshore wind turbines, as a consequence of a higher degree of standardization and extensive experience in the construction of these plants and the corresponding contracts (FIDIC). The size of the turbines and the turbine power are increasing all the time (so fewer turbines will ultimately be needed for the same capacity). At the same time, the life span of the plants by far exceeds the amortization period. All this promises huge profits in the long run, so operators are willing to offer very low bids.

BMWi, "Nationale Ausschreibungen und Ergebnisse," online: <www.erneuerbare-energien.de/EE/ Navigation/DE/Recht-Politik/EEG-Ausschreibungen/Nationale-Ausschreibungen/nationaleausschreibungen.html>. BMWi, "EEG-Vergütung und Kapazitätszuweisung," online: <www.erneuerbare-energien.de/EE/ Navigation/DE/Technologien/Windenergie-auf-See/Finanzierung/EEG-Verguetung/eegverguetung.html\#doc153466bodyText1>.

175 BNetzA, Press Release, "Bundesnetzagentur Erteilt Zuschläge in der Ersten Ausschreibung für OffshoreWindparks"(13 April 2017), online: <https://www.bundesnetzagentur.de/SharedDocs/Downloads/DE/ Allgemeines/Presse/Pressemitteilungen/2017/13042017_WindSeeG.pdf?_blob=publicationFile\&v=3> [BNetzA Press Release].

176 Ibid; Andreas Mihm, "Windstrom Geht Auch Billiger," Frankfurter Allgemeine Zeitung (21 April 2017), online: <www.faz.net/aktuell/wirtschaft/energiepolitik/kommentar-windstrom-geht-auch-billiger-1498 0201.html $>$.

177 NERA Economic Consulting, "Method or Madness: Insights from Germany's Record-Breaking Offshore Wind Auction and Its Implications for Future Auctions" by Dominik Hübler, Daniel Radov \& Lorenz Wieshammer (2 May 2017) at 3, online: <www.nera.com/publications/archive/2017/methodor-madness--insights-from-germanys-record-breaking-offsho.html>; Jakob Schlandt, "Die OffshoreSensation und Ihre Fallstricke," Bizz Energy Weekly (20 April 2017), online: <bizz-energy.com/ die_offshore_sensation_und_ihre_fallstricke >; Franz Hubik, "Preissensation bei Offshore-Windenergie," Hañdelsblatt (13 April 2017), online:<www.handelsblatt.com/unternehmen/industrie/erneuerbareenergien-preissensation-bei-offshore-windenergie-/19671984-all.html>; Andreas Mihm, "Null Cent für den Strom vom Meer," Frankfurter Allgemeine Zeitung (20 April 2017), online: <www.faz.net/aktuell/ wirtschaft/energiepolitik/windparks-auf-see-null-cent-fuer-den-strom-vom-meer-14978662.html $>$. 
- The TSO provides offshore grid connection and converter stations to the winners at no cost (the costs are being charged to the energy consumers by grid surcharges). Winners also have a statutory guarantee of timely completion of these facilities, and a right to be compensated for damages due to delay.

- Currently the cost of debt is low due to very low interest rates. This increases leverage, given that such investments are usually made with an equity ratio of 50 percent. In any event, investors seem to expect an increase of the net present value of their investment, since the decreasing risk of project failure (due to better experience values) allows a smaller calculated interest rate.

- By investing in offshore wind turbines, some operators may intend to hedge future losses in coal-powered generation. Since the politically induced market exit of coalpowered generation is expected to lead to an increase in electricity prices, investments in wind turbines will likely absorb losses from the coal power sector.

- $\quad$ Bidders wanted to avoid the risk of sunken costs for money already spent for developing the projects. A total volume of 6,000 to 7,000 MW of permitted projects were admitted to participate in the auction. ${ }^{178}$ The ones that did not win in the auction faced the depreciation of their investment (sunk costs), unless they were prepared to bet on successful future auctions. In 2018, there will be only one additional auction with a volume amounting to $1.610 \mathrm{MW}$. For the following years, only smaller volumes ( $800 \mathrm{MW})$ will be tendered. For this reason, many operators bet low in the auction to secure their market share. If electricity prices do not develop as expected, bidders may withdraw their bid by making a moderate penalty payment.

As Alberta plans to withdraw from coal-powered generation by the year 2030, it is possible that electricity producers in Alberta will also bid strategically low in order to bet on the increase of electricity prices and to hedge for losses in the coal sector.

In Great Britain, the CFD regime gave a stark illustration of the power of competition as a means of determining the level of CFD strike prices. The first British CFDs were awarded early, in 2014, outside the competitive process described above. ${ }^{179}$ The UK's Competition and Markets Authority subsequently calculated that the costs to customers of the offshore wind projects awarded these early CFDs was between 30 to 60 percent higher than the support cost of similar projects awarded CFDs through the first competitive allocation round less than a year later. This was equivalent to "approximately $£ 250-310$ million per year for 15 years, [or] a 1 percent increase in retail [power] prices." 180

BNetzA Press Release, supra note 175.

These contracts were awarded as a result of a process that began and ended before the legislative and regulatory provision for the competitive CFD allocation was completed: see UK Government, Department of Energy \& Climate Change, Press Release, "Government Unveils Eight Major New Renewables Projects, Supporting 8,500 Green Jobs” (23 April 2014), online: <https://www.gov.uk/ government/news/government-unveils-eight-major-new-renewables-projects-supporting-8500-greenjobs $>$.

UK Competition and Markets Authority, Energy Market Investigation: Final Report (24 June 2016) at para 56, online: <https://assets.publishing.service.gov.uk/media/5773de34e5274a0da3000113/finalreport-energy-market-investigation.pdf $>$. 
Competition is a powerful tool. To make it work effectively, authorities in Alberta must ensure:

- that the regime does not impose unnecessary costs that are likely to increase the level of successful bids;

- that the amount of capacity likely to be eligible for each tender procedure significantly exceeds the amount of capacity that will be awarded contracts in that tender; and

- that an appropriate maximum price is set (as in both the German and British auction models).

Since it may be necessary to adjust tender rules to match the characteristics of the market, those administering the tender process need to have good market intelligence and must analyze the market precisely. ${ }^{181}$ The impact of other aspects of the regime (such as the level of penalties for non-delivery, discussed further below) also needs to be taken into account when seeking to maximize incentives to bid low in an auction.

With respect to setting a maximum price, Alberta appears to be doing this in a different manner than Great Britain or Germany. Many jurisdictions tender for a certain number of MW of capacity, but set a per MWh maximum bid price (as in Germany). Great Britain does not have a MW target, but sets an allocation round budget cap and per MWh maximum strike prices. In both cases, the relevant figures are all published in advance. Instead, Alberta has an - apparently undisclosed - "affordability threshold" "182 for each auction. If the threshold is set in advance and is not based on unrealistic expectations of project costs, this is perfectly fair, but the lack of transparency on the affordability threshold is novel and not without risk.

\section{AuCTION DESIGN}

When designing a renewable support auction mechanism, there is a choice to be made with respect to the quantity to be tendered. Alberta is following the majority of regimes, like Germany's EEG, which specify the maximum amount of capacity (in MW) to be supported, and leave it to the competitive process to drive down the prices. The British CFD regime, on the other hand, seeks to cap the overall costs of a tender round ex ante, by specifying the maximum amount of support (in $£$ ) that will be available. Is Alberta missing a trick by not following the British approach? On balance, we think not.

- The supposed greater control of subsidy costs in Great Britain's CFD allocation rounds depends heavily on the accuracy of the assumptions used when estimating the costs of each project. If estimates of the market reference price are too high (but are still below the level of strike price bids) or estimates of the load factor for a

181 BMWi, Ausschreibungsbericht nach § 99 Erneuerbare-Energien-Gesetz (EEG 2014), online: <www . erneuerbare-energien.de/EE/Redaktion/DE/Downloads/Berichte/bericht-pilotausschreibungen.pdf?

blob $=$ publicationFile $\& v=5>$.

182 AESO, REP Recommendations, supra note 55, s 5.2 
particular technology are too low, the subsidy cost of projects will be underestimated and the actual costs may exceed the budget cap. ${ }^{183}$

- $\quad$ By choosing a pay as bid auction design, Alberta may increase the risk of projects not being delivered, because it holds those who bid very low strike prices to those prices rather than lifting them up to the auction clearing price (if that is higher). However, the risk of uneconomic bids has probably been adequately mitigated by imposing stiffer penalties for non-delivery than apply in Great Britain (see below). In any event, the first CFD allocation round in Great Britain's experience shows that a pay as clear regime is not necessarily immune to the "winner's curse" syndrome. ${ }^{184}$ Moreover, a pay as bid regime can help to ensure that a project is not overpaid as a result of a clearing price that is higher than the level of its own (viable) bid. ${ }^{185}$

Another question is to consider whether all eligible projects should compete against each other.

- Great Britain has grouped projects into "more" and "less" established technologies, and requires projects of different technologies in those groups to compete with each other. BEIS can reserve parts of the budget for specific technologies, but little use has been made of this facility. ${ }^{186}$

The 23 percent increase in load factor for valuing offshore wind contracts for the 2017 CFD allocation round, as compared with the 2015 allocation round, suggests that the costs of offshore wind projects in the earlier round may have been underestimated. See UK Government, Department of Energy \& Climate Change, Contract for Difference: Final Allocation Framework for the October 2014 Allocation Round (2 October 2014), Appendix 3, online: <https://www.gov.uk/government/uploads/system/uploads/ attachment_data/file/404405/Contract_for_Difference_Final_Allocation_Framework_for_the October $20 \overline{1} 4$ Allocation Round.pdf $>$; Allocation Framework, supra note 123 , Appendix 3. This would not be the first time that subsidy estimates have been based on an underestimate of the efficiency of wind turbines. See Matthew Lockwood, "The UK's Levy Control Framework for Renewable Electricity Support: Effects and Significance" (2016) 97 Energy Policy 193.

184 In their eagerness to secure CFDs, two solar farms that competed in the first UK CFD auction put in bids of $£ 50 / \mathrm{MWh}$, which they rightly judged were low enough to guarantee that they would be offered a CFD. Unfortunately, they were also the only bids in respect of the delivery year 2015-2016, and therefore they set the clearing price for that year at a level that they could not, in fact, afford. Under the British regime in force at the time, they were able to decline the offer of a CFD, and were ultimately able to sell the project rights to third parties who managed to build out most of the capacity concerned in a different configuration under the pre-existing subsidy regimes instead. However, if a project found itself unable to proceed at the strike price it was awarded in the 2017 auction and did not sign a CFD, the site would effectively be excluded from the next two auctions. See Contracts for Difference (Allocation) (Amendment) Regulations 2015, SI 2015/981 and Contracts for Difference (Allocation) (Excluded Sites) Amendment Regulations 2016, SI 2016/1246.

185 The standard economist's view is that a project which bids $\$ 50 / \mathrm{MWh}$ and ends up with a clearing strike price of $\$ 100 / \mathrm{MWh}$ is being rewarded for its efficiency as compared with other generators - just as would be the case in bidding into a power pool. Another way of looking at the same facts, which may intuitively commend itself to consumers and politicians, is to say that the project made a lucky gamble and received a windfall.

The mechanism has been used only in respect of one technology or technology group in each of the first two CFD auctions. See UK Government, Department of Energy \& Climate Change, "Budget Notice for CFD Allocation Round 1" (2 October 2014) at 3, online: <https://www.gov.uk/government/uploads/ system/uploads/attachment_data/file/360129/CFD_Budget_Notice.pdf>; UK Government, "Second Round Budget Notice," supra note 122 at 2. 
- In spite of a strong policy directive towards all-against-all competition at the EU level, ${ }^{187}$ most European countries, such as Germany, have not adopted the same approach as Great Britain, and only require projects to compete against other projects of the same technology.

- Alberta may wish to consider this point in relation to solar power. At present, the solar sector in Alberta is limited, but the solar resources of at least parts of Alberta are superior to those of most of Great Britain. The British experience has been that as soon as a substantial subsidy mechanism becomes available to solar projects, the sector grows rapidly. ${ }^{188}$ Solar technology has the potential to become cheaper more quickly than wind power, so it is possible that solar projects could undercut wind projects if the two technologies compete against each other.

- If Alberta's policy is to encourage smaller generators or less mature technologies, it may wish to reserve part of the auction or change some of the terms based on generating capacity or technology type (for example, the penalties for non-delivery could be reduced). ${ }^{189}$ All-against-all auctions will naturally favour larger players, bigger projects, and more established technologies.

\section{ENSURING DELIVERY}

It makes little sense to award contracts to projects that will deliver a great deal of electricity at a very low subsidy cost per MWh if those projects are not built. There are essentially two ways of ensuring delivery of bid-winning projects. One is to try to screen projects and bidders before allowing them to compete; the second is to penalize non-delivery. As we have seen, the REP and the three comparator jurisdictions adopt different mixes of both techniques. In particular, the British regime differs from the others in not requiring bidders to give any financial security, and (in contrast with Alberta's proposals) it does not involve any scrutiny of a project's finances or the track record of the developers. Does this "light touch" approach bring an increased risk of non-delivery?

The British CFD regime relies heavily on two assumptions. First, because of the substantial costs involved in obtaining the consents and connection agreement necessary to enter into a project for the auction process, developers will be reluctant not to proceed if awarded a CFD. Second, once a project has been awarded, it is likely to be completed at the

Commission Guidelines, supra note 69 at para 109.

Between 2014 and 2016, in order to control subsidy costs, the British government closed the RO two years ahead of schedule for solar projects of $5 \mathrm{MW}$ and above and a year ahead of schedule for those below $5 \mathrm{MW}$, and effectively abolished FiT payments for all but the smallest solar projects. See UK Government, Department of Energy \& Climate Change, Government Response to Consultation on Changes to Financial Support for Solar PV (2 October 2014), online: <https://www.gov.uk/government/ uploads/system/uploads/attachment data/file/360280/Government_response_RO-FIT changes to

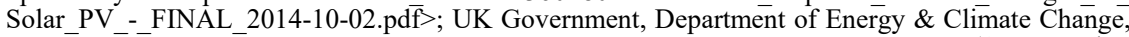
Government Response to Consultation on Changes to Financial Support for Solar PV (17 December 2015), online: <https://www.gov.uk/government/uploads/system/uploads/attachment_data/file/486091/ 20151216_Small_scale_solar_PV_government_response_FINAL.pdf $>$; UK Government, Department of Energy \& Climate Change, Review of the Feed-In Tariffs Scheme (17 December 2015), online: $<$ https://www.gov.uk/government/uploads/system/uploads/attachment_data/file/487300/FITs_Review_ Govt_response_Final.pdf>. 
time intended in the CFD contract. The evidence suggests the first assumption is typically met; the second is in doubt. ${ }^{190}$

The REP takes a different line. Developers may, at least in theory, bid for RESA support without having secured all the necessary consents for their project, but the supporting evidence they must introduce at the RFQ stage is much greater than the Great Britain regime requires at any point, covering in detail matters such as the developer's track record, the availability of equity finance, and the financial position of those providing that finance none of which are featured in the UK process. ${ }^{191}$ Bidders at the RFP stage must maintain completion and performance security of $\$ 50,000$ per MW in the form of a letter of credit, which serves as the measure of liquidated damages that a generator will have to pay if it fails to commence construction by the Commencement of Construction Longstop Date (CC Longstop Date). In the case of Round 1, this date is apparently December 2019, which also serves as the Target COD (or commercial operation date). Failure to achieve commercial operation of the project by this date results in a shortening of the support period on a day-forday basis (with the same effect as under a Great Britain CFD). A continued failure to achieve commercial operation 18 months later results in liquidated damages on the same basis as failure to commence construction by the CC Longstop Date. ${ }^{192}$

In support of Alberta's approach, the results of the German EEG auctions suggest that in order to avoid speculative bids that may be little more than a gamble on future movements in electricity prices, the penalties for non-delivery need to be substantial. Bidding and scrutinizing bids will cost more, but this may be a price worth paying. The following further points are worth considering:

- Commencement of construction (for the purposes of determining whether the CC Longstop Date has been met) is defined to include the generator having obtained the necessary consents and permits, secured financing sufficient to complete the development, procured or entered into arrangements for long-lead items necessary

The date set in 10 CFDs as the Target Commissioning Date for the projects to which they relate had been reached. Five of those projects (three offshore wind farms and two solar farms) have been completed or are very close to being completed. One of the solar farms experienced some difficulties (with timely grid connection) and was completed later than originally expected. One project (a solar farm whose developer appears to have collapsed as a consequence of changes to other UK solar subsidies) has had its CFD terminated. Four projects (two onshore wind farms and two conversions of old coal-fired plant to burn biomass) are still some way from being completed. Progress on the biomass plants was substantially affected by delays in securing clearance for their CFDs from the European Commission under EU state aid rules. One of the onshore wind farms was delayed because it made a further application for planning permission after obtaining its CFD in order to be able to deploy larger turbines; although ultimately successful, this application was initially refused. The other onshore wind farm has been delayed by difficulties in satisfying conditions imposed as part of its planning permission. As noted above, two solar projects won CFDs in the 2015 allocation round, but did not sign their contracts. Neart na Gaoithe, an offshore wind project that was among the successful bidders in 2015, lost its development consent as a result of a legal challenge in July 2016. As a result, it was unable to proceed and the LCCC sought (unsuccessfully) to exercise its right to terminate the project's CFD for failure to meet Milestone Requirements set out in the standard CFD terms. However, that may not be the end of the matter, as the Scottish Court of Session has now overturned the first instance decision to quash the development consent. See generally Low Carbon Contracts Company, "CFD Register," online: $<$ https://lowcarboncontracts.uk/cfds?field_cfd_technology_type=\&field_cfd_applicant_name $=\&$ field_cfd_unique_id=>. On Neart na Gaoithe specifically, see RSPB v Scottish Ministers, [2017] CSIH 31 (Scot), online: BAILII <www.bailii.org/scot/cases/ScotCS/2017/[2017]CSIH31.html>. AESO, REP Recommendations, supra note 55 at 15.

192 Draft RESA, supra note 94, ss 1.1 ("Commencement of Construction Longstop Date," "Target COD," and "Support Period"), 11, 15, 16. 
to construct the project, and delivered a copy of its financial model to the AESO as well as actually having begun construction work on site. ${ }^{193}$ This equates fairly closely to the Milestone Requirement under a UK CFD, but the generator is given two years, rather than one, to reach this stage. ${ }^{194}$ So although the penalties for failure may be more severe, the target itself may be less demanding for a project of comparable maturity in each jurisdiction. There seems to be no point between the RFQ and COD at which the progress of the project is officially evaluated, with consequences for the developer if satisfactory progress has not been made. During the equivalent period under the CFD regime, the contractual milestone requirements perform this function and appear to have served a useful "early warning" purpose. The authorities in Alberta may wish to consider introducing similar requirements as conditions precedent to the RESA.

- As in Great Britain's regime, the generator can avail itself of force majeure protection in relation to failure to meet either the CC Longstop Date or the COD Longstop Date. It may also be able to avail itself of change in law protection. In general, the scope of the RESA's force majeure protection appears to be intentionally broad. It includes "delays or disruptions ... in the construction of any Connection Facilities that are required for the Facility to Deliver Electricity;" 195 and the "inability to obtain [or renew] any permit, certificate ... licence or approval of any Governmental Authority ... required [for] perform[ance] ... unless caused by the action or inaction of the Party invoking Force Majeure. ${ }^{, 196}$ However, it also states that force majeure will not include an appeal of the permit and licence in respect of the project - unless the appeal does not relate to a wrongful or negligent act of the generator and the generator is ordered to cease construction for the duration of the appeal. ${ }^{197}$

- The AESO will be able to terminate the RESA for convenience on 30 days notice at any time before the project begins commercial operations. ${ }^{198}$ This seems to detract from what is often thought of as one of the main strengths the type of regime that the REP proposes, namely that paying subsidies under a private law contract confers greater security against political risk. It is not obvious what is gained in policy terms by the AESO having this termination right. It is subject to an obligation to pay the generator's reasonable development costs, up to a specified amount, if exercised before commencement of construction, and to an obligation to compensate the generator's costs of project financing and equity invested, subject to certain deductions. ${ }^{199}$ The cost to the Alberta government if this right is exercised may be sufficient to deter its use in practice, but its existence may well increase project financing costs. 


\section{RENEWABLE SUPPORT AND Other REVENUE STREAMS}

Under the proposed REP, there are limits on a generator's ability to earn income other than by selling power or through payments made to it by the AESO under the RESA itself. These restrictions are not paralleled in the British CFD regime. While some of them may be motivated by factors affecting the AIES which are not found in Great Britain, we question whether it is desirable to introduce further distinctions between REP projects and the rest of the market.

- As may be expected, RESA payments replace whatever revenue a project might have otherwise made from selling renewable energy certificates. The generator is required to transfer to AESO title to all Renewable Attributes. ${ }^{200}$ These are broadly defined in the draft RESA (although specific income tax benefits are excluded) and include emission reduction credits. ${ }^{201}$ The British CFD regime generally prevents projects from benefiting from more than one of the main renewable subsidy schemes, but it did not, for example, exclude projects from a carbon offsetting scheme while in force. ${ }^{202}$

- Under the RESA, the generator will not be permitted to sell ancillary services. ${ }^{203}$ The thinking here is not clear, but it would appear to set REP projects further apart from the rest of the market. For some renewable generating facilities (for example, solar farms) this may make little difference, but for others (for example, biomass plants) it may entail a material loss of revenue that could make their strike price bids less competitive. There is no parallel for this restriction in Great Britain's CFD regime. If it is maintained, the pool of plants able to provide ancillary services may gradually shrink until it includes only fossil fuel plants, most of which may be in receipt of subsidies in the form of capacity payments. Moreover, although the Alberta ancillary services market is currently small, experience from other markets suggests that growth in the share of renewables on the system (particularly solar) will lead to an increase in demand for ancillary services. At the same time, as battery and other energy storage technologies become cheaper, there is a good chance that renewable projects linked to storage facilities will themselves be well placed to provide such services as they move from being intermittent to quasidispatchable generation (see further below). ${ }^{204}$

Ibid, Appendix 1, Schedule 4, Recital A.

Ibid, s 1.1 .

In the UK, the climate change levy is payable by suppliers (retailers) on supplies of electricity to business customers. Historically, where the electricity supplied was generated from renewable sources, it was exempt from the levy, such exemption being embodied in levy exemption certificates (LECs) issued in respect of each MWh of renewable electricity generated by qualifying installations. The sale of LECs, similar to that of ROCs, had a commercial value to generators (around $£ 5$ or $£ 6$ per LEC). LECs were abolished quite suddenly in 2015, but before their abolition there had been no suggestion that they would not be issued to CFD projects.

Draft RESA, supra note 94, s 5.2(c).

For a pioneering wind-and-battery plant, see Energy Storage Association, "Frequency Regulation Services and a Firm Wind Product AES Energy Storage Laurel Mountain Battery Energy Storage (BESS)," online: <energystorage.org/energy-storage/case-studies/frequency-regulation-services-andfirm-wind-product-aes-energy-storage $>$. 
- $\quad$ Finally, the generator is required to bear the risk of curtailment (in its entirety for the first 200 hours and shared with the AESO thereafter). This could be a significant risk for wind power in particular, which not infrequently finds itself directed to curtail its output. ${ }^{205}$ In Great Britain's regime, for example, there is compensation in cases of curtailment, admittedly through the transmission charging regime rather than the CFD. To the extent that AESO has discretion in determining which of two plants to direct to curtail at a particular time, generators in Alberta would want to be reassured that it is not open to AESO to decide which plant to constrain on the basis that one plant has yet to reach the 200 hour threshold and the other has already exceeded it.

In Alberta, generators with a RESA will be required to sell all their power into the pool. ${ }^{206}$ This requirement, coupled with the likelihood that much of the capacity concerned will be generated from intermittent renewable resources, will likely reduce pool prices further. The provisions summarized above mean that the RESA is far from over-generous in its provision for other potential generator revenue streams. As a result, strike price bids may be driven up, and REP plants will be more separated from the rest of the market than is necessary.

Another related area for future consideration in Alberta is negative power prices. These have become an occasional feature of European markets with large renewable generation as a means to discourage generation. If the market reference price is $-10 / \mathrm{MWh}$ and the strike price is $40 / \mathrm{MWh}$, should the generator be paid 50? The consensus among European regimes is, in effect, not for long. The European Commission does not believe that a premium should be paid during periods of a negative price market. In Germany, Italy, and Great Britain, no subsidy is paid when prices are negative for 6 or more consecutive hours. Danish offshore wind farms are paid no subsidy at all during any period of negative pricing. In France, payments are only made during the first 20 hours of negative pricing each year. ${ }^{207}$

\section{LOCATION, LOCATION, LOCATION (AND StORAGE)}

The REOI states that

[t]he capacity of the [AIES] will not be expanded to accommodate REP Round 1 projects. Accordingly, all successful Renewable Projects must be located where the available capacity of the relevant region of the AIES, under system normal conditions, can accommodate at least 100 per cent of such project's contract capacity. $^{208}$

The RFQ confirms that no project will be selected for a RESA in Round 1 if its operation would require reinforcement of the existing grid infrastructure. ${ }^{209}$ This criterion will be applied cumulatively as well as to individual projects; it is not entirely clear how the cumulative assessment will interact with the ranking of the bids at the RFP stage. This

Draft RESA, supra note 94, s 7.1(a).

Ibid, Appendix 1, Schedule 4, Recital A.

For a description of European practices, see the state aide decisions cited at supra note 69.

REOI, supra note 91 at 3.

RFQ, supra note 94, s 3.1(h). 
measure and the concerns it is presumably designed to address bear further consideration in the light of international experience.

- New supply of wind and solar energy is not always located near centres of electricity demand or near transmission lines that can accommodate this new generation. Sooner or later, significant expansion of renewable generation tends to require expansion of the transmission and distribution networks.

- The cost of transmission capacity expansion must ultimately be passed on to electricity customers or taxpayers. Given a choice between a $100 \mathrm{MW}$ project that can be fully deployed without additional transmission investments and one that requires network expansion (or will face frequent curtailment without network expansion), the former option should be better value for money, and is more likely to be completed within two years of being awarded a RESA. But what if the first project is likely to have a 3 percent lower load factor? What is the trade-off between expanding long-term renewable energy expansion and mitigating the costs of grid expansion?

- In Great Britain, onshore wind is increasingly concentrated in Scotland, because its wind resource is strongest, and the devolved government (unlike England and Wales) favours onshore wind development. However, electricity demand is strongest in England, and there was insufficient existing transmission capacity, especially between Scotland and England, to handle all the Scottish wind electricity expansion. New projects are still allowed to connect, provided the so-called "enabling works" or wider transmission system reinforcement is completed. ${ }^{210} \mathrm{~A}$ user commitment may be required, forcing a generator to contribute towards system reinforcement works once they have been started, even if its project does not go ahead. In the meantime, projects accept that export of power will sometimes be constrained by the network operator, but when connected to a transmission network they generally receive compensation (for example, through the balancing mechanism).

- Germany also needs more network infrastructure to connect wind resources (particularly offshore) concentrated in the North with demand in the South. For onshore wind, the EEG 2017 auction mechanism includes adjustments known as the Referenzertragsmodell, allowing projects with relatively weaker estimated wind resources to bid on more equal terms, subject to a subsidy clawback if the load factor turns out to be higher. For offshore wind, the German authorities went a step further and adopted the successful Danish "centralized" model. For projects that will become operational from 2026 onwards, the State pre-qualifies a site by carrying out environmental and other studies, issuing a consent, and then inviting connections/Industry-products/connect-and-manage/>. There is a public relations downside in that the regime results in payments to generators by National Grid which are indignantly characterized by those opposed to onshore wind (including a number of right-wing newspapers) as "wind farms being paid not to generate." See e.g. Robert Mendick, "Wind Farms Paid $£ 1 \mathrm{~m}$ a Week to Switch Off," The Telegraph (4 January 2015), online: <www.telegraph.co.uk/news/earth/energy/windpower/11323685/Wind-farmspaid-1m-a-week-to-switch-off.html $>$. 
developers to bid for a specified number of MW. This avoids wasting capital on bidding sites that will not qualify for subsidies in the competitive auction process. ${ }^{211}$

As Alberta looks beyond the first REP auction, it is worth considering the approaches adopted in Great Britain and Germany as ways of maintaining confidence in a pipeline of development projects, ensuring that there is sufficient competition in each auction, and coordinating the spread of renewable generation deployment with the development of transmission and distribution networks.

Co-location of renewable energy production with energy storage facilities is another way of managing the demands on transmission grid infrastructure.

- Instead of balancing intermittent renewable supply with demand and transmission capacity at any given time, energy could be stored and released when it is needed and can be transmitted.

- $\quad$ Storage should save on network expansion costs. For a generator who can time sales in a purely market-based system, getting a better price per MWh could balance the financial cost and power loss associated with the storage process.

- If long-term markets come to be dominated by intermittent wind and solar, large scale storage facilities will be needed. Targeted subsidies could stimulate investment in storage technologies, just as they encouraged investment in renewable generation technologies.

California has been a pioneer in this area. ${ }^{212}$ The German EEG 2017 regime provides for separate tender processes to take place from 2018 for innovative projects, such as those incorporating storage. ${ }^{213}$ In Great Britain, some thought has gone into adapting the CFD regime for projects with storage, ${ }^{214}$ and AESO is considering storage as well. ${ }^{215}$ Alberta's

Germany SA, supra note 69 at 59ff (onshore wind) and $71 \mathrm{ff}$ (offshore wind). It is conceivable that the German legislature will even reshape Germany's electricity market by separating the market in the North from the market in the South. This might lead to a situation where operators from the northern part of the country will not be able to generate the same margins as operators from the southern part. California Public Utilities Commission, "Energy Storage," online: <www.cpuc.ca.gov/General.aspx? id $=3462>$.

EEG 2017, supra note 134, §39j.

BEIS has addressed the key question of metering (from a generator's point of view, metering output for CFD purposes should be done between the renewable generating facility and the storage facility, so that the generator can benefit from any market price upside to be gained by deferring the export of power to the grid): see UK Government, "Contracts for Difference: Government Response to the Consultation on Changes to the CFD Contract and CFD Regulations" (February 2017) at 15-19, online: <https:// www.gov.uk/government/uploads/system/uploads/attachment_data/file/589996/FINAL_-

Government Response to the CFD Contract Changes Consultation.pdf $>$. Meanwhile, BEIS and $\overline{\mathrm{O}}$ fgem are considering the wider issues raised by $\bar{h}$ aving a higher proportion of inflexible generation on the grid: see UK Government, A Smart, Flexible Energy System: A Call for Evidence (November 2016), online: Ofgem $<$ https://www.ofgem.gov.uk/system/files/docs/2016/12/smart_flexible_energy system a call_for_evidence.pdf $>$; Ofgem, Targeted Charging Review: AConsultation (13 March 2017), onlinē: $<\overline{\mathrm{h} t \mathrm{tps}} \overline{\mathrm{A}} / / \mathrm{www}$.ofgem.gov.uk/publications-and-updates/targeted-charging-review-consultation>. For commentary, see Claudine Raffray \& Adam Brown, "Strong and Stable, or Storing Up Trouble? The Outlook for Energy Storage Projects in the UK" (31 May 2017), Dentons Global Energy Blog (blog), online: <www.globalenergyblog.com/strong-and-stable-or-storing-up-trouble-the-outlook-for-energystorage-projects-in-the-uk>.

215 Alberta Electric System Operator, "Energy Storage," online: <https://www.aeso.ca/market/currentmarket- initiatives/energy-storage/>. 
natural resources are well-suited to some very large-scale storage technologies. Adapting the REP framework could make the province a leader in integrated wind and solar storage development. $^{216}$

\section{Transition to a Parallel Capacity Market: analysis ANd Comparison of Alberta's Proposals}

\section{A. Alberta's Plans: At a Formative Stage}

As noted above, the AESO is tasked with the significant undertaking of designing and implementing the parallel capacity market. Stakeholder engagement on market design began in the first quarter of 2017. The AESO procurement process is expected to begin in 2019, which coincides with the next provincial election. This timing introduces an element of doubt as to whether the first contracts will be awarded as anticipated in 2020. The AESO currently expects the capacity market will be in place by $2021 .^{217}$

Although the capacity market proposals complement the REP, their development is less advanced and therefore harder to assess or compare with fully developed regimes in other jurisdictions. In this part of the paper we will focus mostly on what has been learned in certain other jurisdictions, recognizing that the economic consultancy Charles River Associates has reported to the AESO on a similar exercise recently carried out on a much more scientific basis. ${ }^{218}$

In its recommendation of October 2016, the AESO states the problem succinctly. There is "considerable uncertainty about whether sufficient investment in non-renewable generation ... will occur in the future." ${ }^{219}$ Coal plants are being retired, and investment in energy-only markets has declined across North America. Less capital is available for new merchant power plants because of significant revenue volatility. Without sufficient new firm generating capacity to back up intermittent wind generation, system reliability will be compromised, and price volatility increased. Even a substantial increase in the pool price cap $^{220}$ was viewed as unlikely to attract sufficient investor interest. ${ }^{221}$

For larger volume and longer-term energy storage, technologies such as compressed air energy storage (CAES) have a number of advantages over battery storage. The most obvious geologies for CAES are underground salt deposits or depleted hydrocarbon reservoirs. Alberta has both. For details of proposed projects, see Rocky Mountain Power, "Alberta-Saskatchewan Intertie Storage (ASISt)," online: < rocky mountainpower.ca/projects/asist/>. CAES has the additional benefit that it can be combined with CCGT projects so as to reduce their gas consumption by at least one third. See e.g. Wenyi Liu et al, "Analysis and Optimization of a Compressed Air Energy Storage—Combined Cycle System" (2014) 16:6 Entropy 3103.

Alberta Electric System Operator, "Capacity Market Transition," online: $<$ https://www.aeso.ca/market/ capacity-market-transition/>.

Charles River Associates, A Case Study in Capacity Market Design and Considerations for Alberta (30 March 2017), online: AESO <https://www.aeso.ca/assets/Uploads/CRA-AESO-Capacity-MarketDesign-Report-03302017-P1.pdf> [Charles River Associates, Study]; Charles River Associates, A Case Study in Capacity Market Design and Considerations for Alberta: Appendices (30 March 2017), online: AESO $<$ https://www.aeso. ca/assets/Uploads/CRA-AESO-Capacity-Market-Design-Report-03302017Appendices.pdf $>$ [Charles River Associates, Appendices]. $7(2)(\mathrm{a})$.

221 See AESO, Transition Recommendation, supra note 66 at 2. 
The key issues were conveniently summarized in a set of slides prepared for a stakeholder event in January 2017. ${ }^{222}$ This document states that a

potential desired end state description [for Alberta's proposed capacity market could be] ... "a capacity market that utilizes competitive market forces, ensures continued supply adequacy and reliability at a reasonable cost and is flexible to reflect the unique aspects of Alberta's electricity industry.,223

It also identifies the following potential starting assumptions from capacity markets in other jurisdictions that reflect the Alberta market:

- A capacity obligation is a forward physical obligation on capacity suppliers that requires the capacity sold in the capacity market to be available to provide energy when needed. This obligation is created when the capacity supplier's offer is cleared in the capacity market.

- All existing capacity "must offer" their eligible capacity to the capacity market. Planned capacity must offer for the delivery year they are connected.

- The capacity market will be designed as a single zone with the capability of adding zones should it be required due to a change in transmission policy or other factors.

- The resource adequacy requirement for Alberta will be centrally determined.

- The capacity market is intended to ensure supply adequacy. Other attributes such as carbon output, total capacity factor, ramp flexibility, energy production costs, etc., are not considered within the capacity market.

- Capacity ... services [is a] separate [product], and [needs to be] procured independently.

- Participants do not need to be successful in the capacity market to participate in the energy and ancillary services markets.

- While receiving support payments, [REP] round 1 winners are not eligible to sell REP capacity in the capacity market owing to the Indexed REC payment mechanism chosen.

- Capacity market mechanics/behaviour will have regulatory oversight. Market outcomes will be the result of market clearing, unless otherwise demonstrated. ${ }^{224}$

Alberta Electric System Operator, "Designing Alberta's Capacity Market" (January 2017), online: $<$ https://www.aeso.ca/assets/Uploads/AESO-Capacity-Market-Stakeholder-Session-Jan-2017Final.pdf $>$. See more recently Alberta Electric System Operator, "Straw Alberta Market (SAM 1.0) Proposal for Discussion (Errata)" (12 May 2017), online: <https://www.aeso.ca/assets/Uploads/Straw23. Alberta-Market-Proposal-formatted-FINAL-errata.pdf> Alberta Electric System Operator, "Designing Alberta's Capacity Market," ibid at 7. 


\section{B. INTERNATIONAL COMPARATORS}

\section{GERMANY}

As noted above, capacity mechanism policies are often driven by concerns that increasing deployment of renewable technologies is undermining the case for new conventional generation capacity, even as it arguably increases the need for such capacity to act as backup for intermittent renewables and baseload. Capacity mechanisms may either choose to cover the whole market, or be targeted on the presumed missing capacity. Like Great Britain and the US, Alberta is following the former route. In this context, Germany is an interesting comparator as it is a jurisdiction where the mass deployment of renewables has had a huge impact on the electricity market, ${ }^{225}$ but it has adopted the more targeted approach for its capacity mechanism.

The German authorities have opted to procure $2 \mathrm{GW}^{226}$ of strategic reserve, to operate alongside and separately from the energy-only market in which generators and other sources of capacity participate. The capacity reserve is established to compensate for energy shortages, when the available balancing energy does not suffice. Participating plants must not participate in the energy market, and must be shut down within four years of deployment in the capacity reserve. Thus, the participating plants are the generating facilities that are being decommissioned in the near future. Plants are contracted by the transmission system operators after a tender process. They do not operate outside of a power shortage. They receive remuneration in accordance with their electrical capacity. This capacity payment is borne by those energy suppliers that fail to meet their supply obligations pro rata to the degree of contribution. The suppliers pass on these costs to their electricity customers. ${ }^{227}$

Since the German approach is so different from that which is currently envisaged in Alberta, we do not examine it further here. Even given the relatively small size of the scheme, the European Commission currently has concerns that it could have an unduly adverse effect on competition. ${ }^{228}$ But it is worth bearing in mind that a market-wide capacity mechanism is not the only way.

Agora Energiewende, "The Energy Transition in the Power Sector: State of Affairs 2015" (7 January 2016), online: < https://www.agora-energiewende.de/fileadmin/Projekte/2016/Jahresauswertung 2016/ Agora_Jahresauswertung_2015_Slides_web_EN.pdf $>$.

226 This is equivalent to a little more than 1 percent of total installed generating capacity in Germany $(205.7$ GW). See BNetzA, "Power Plant List" (20 April 2017), online: < https://www.bundesnetzagentur. de/cln_1411/DE/Sachgebiete/ElektrizitaetundGas/Unternehmen_Institutionen/Versorgungssicherheit/ Erzeugungskapazitaeten/Kraftwerksliste/kraftwerksliste-node.html $>$.

227 See Paragraph 13 e (3), Sentence 4 of Energiewirtschaftsgesetz (German Energy Industry Act) ("EnWG"), which is the short title for Gesetz über die Elektrizitäts - und Gasversorgung (7 July 2005, last amended on 20 July 2017), online: <https://www.gesetze-im-internet.de/enwg_2005/>, in conjunction with Paragraph $13 \mathrm{~h}$ of the EnWG and Paragraph 33 of KapResV. Paragraph 13 e' (3), Sentence 4 of the EnWG states that system operators are allowed to pass on the costs which are borne on the regulation, pursuant to Paragraph $13 \mathrm{~h}$ of the EnWG, to their electricity customers after having discounted their network charges. Paragraph 33 of the KapResV is a provision of the Kapazitätsreserverordnung (German Capacity Reserve Ordinance) specifying details related to the discount mechanism mentioned above. The KapResV is an ordinance by the German Federal Government based on Paragraph $13 \mathrm{~h}$ of the EnWG. It has not entered into force yet. The draft of the ordinance is published online: BMWi <https://www.bmwi.de/Redaktion/DE/Downloads/V/verordnungkapazitaetsreserveverordnung-kapresv.pdf? $\quad b l o b=$ publicationFile $\& v=1>$.

228 European Commission, "State Aid SA.45852 $(2017 / \mathrm{N})$ - Germany Capacity Reserve," Letter to the German Government (7 April 2017), online: <ec.europa.eu/competition/state_aid/cases/269083/269 $083 \quad 1890897 \quad 10$ 2.pdf>. 


\section{GREAT BRITAIN}

The principle of Great Britain's capacity market is simple: keep the lights on when the system is under stress and reduce the risk of blackouts or brownouts - something for which UK consumers have little tolerance due to historic stability and high margins of capacity over peak demand.

Capacity is procured through annual auctions conducted by National Grid. These are open to both existing capacity and proposed new capacity, including both generating plants and demand side response (DSR). For each delivery year (beginning in October), auctions are first carried out four years ahead (to allow time for construction of new plants). BEIS estimates the amount of reliable capacity required, and sets a cap on the amount per $\mathrm{kW} / \mathrm{year}$ to be paid for it. Starting at that price, bidding takes place in successive rounds of an auction in which the price is gradually reduced until those bidders who are classified as price makers rather than price takers (broadly speaking, new projects) are not prepared to accept a lower price. All bidders receive the clearing price set at that point. New projects receive up to 15 years of capacity payments; existing capacity providers receive support for only one year at a time. $^{229}$

Between the auction and the delivery year, successful new projects must meet a series of milestones. Failure to do so, or to be ready to deliver in the delivery year, results in significant financial penalties - up to $£ 35,000 / \mathrm{MW}$ in some cases. The risk of incurring such penalties, or those for failure to deliver capacity in response to National Grid's signal, is all the more real because the regime contains no change in law protection, and expressly excludes the concept of force majeure relief. ${ }^{230}$

One year before the delivery year, a further auction takes place to adjust for any shortfalls that have arisen because new projects have been abandoned or are behind schedule, or because BEIS's estimate of demand has increased. In the delivery phase, at times of system stress, National Grid is able to call on capacity providers to provide capacity - either by ensuring that they generate and export power to the grid or by not drawing power from the grid. Failure to respond to a system stress event as required by National Grid results in the loss of capacity payments - up to and including all the capacity payments that a participant would otherwise have been entitled to receive in a given year. ${ }^{231}$

This is a slight simplification: see UK Government, Consolidated Version of the Capacity Market Rules (19 July 2017), rules 1.2 ("Maximum Obligation Period"), 5.5.14(b), online: Ofgem <https://www. ofgem.gov.uk/system/files/docs/2017/07/consolidated_capacity_market_rules.pdf $>$ [CMRules]. Some refurbished existing plants may be awarded agreements of up to three years, and some new plants can gain an advantage for themselves by bidding for less than 15 years in some circumstances (ibid, $\mathrm{r}$ 5.9.5(c)). However, most end up with a full 15 years: see e.g. National Grid, Provisional Auction Results: T-4 Capacity Market Auction 2020/2021 at 7, online: <https://www.emrdeliverybody.com/ capacity $\% 20$ markets $\% 20$ document $\% 20$ library/provisional $\% 20$ results $\% 20$ report $\% 20-\% 20 \mathrm{t}-4 \% 20$ 2016.pdfs.

$230 \quad$ CM Rules, ibid, r 6.9.1.

231 For an overview produced shortly before the first auction in 2014, see UK Government, Department of Energy \& Climate Change, "Capacity Market" by Fergal McNamara (25 June 2014), online: $<$ https://www.gov.uk/government/uploads/system/uploads/attachment_data/file/335760/capacity_ market policy presentation.pdf $>$. For further detail, see UK Government, "Electricity Market Reform: Capacity Market," online: < https://www.gov.uk/government/collections/electricity-market-reformcapacity-market>. 
The Great Britain capacity market has yet to be properly tested in terms of capacity delivery. With the exception of a small-scale transitional auction for a small amount of DSR capacity, the auctions that have so far been held have either been procuring capacity for delivery four years ahead (for example, the 2014 auction was aimed at first delivery in 2018-2019) or otherwise for periods that have not yet begun (for example, most recently, an auction was held in January 2017 for delivery in the winter of 2017-2018).

\section{UNITED STATES}

Capacity mechanisms of one sort or another have been developing in the US for almost 20 years. Today they exist in the ISO-NE, the New York Independent System Operator (NYISO), PJM, and the Midcontinent Independent System Operator (MISO). There is no space here to review all aspects of these regimes. ${ }^{232}$ Instead, we focus on two issues that have been recently raised with respect to capacity markets in the US. One topic that has been a recent focus of debate in US capacity markets is performance incentives. The second topic is the impact of changes to one capacity market that impact an interconnected capacity market.

ISO-NE and PJM capacity markets have both had failures that led them to adopt somewhat controversial pay-for-performance rules. PJM's capacity market is a three-year forward capacity market, using an annual auction and subsequent incremental auctions held closer in time to the relevant delivery year. ${ }^{233}$ Similarly, ISO-NE has a three-year Forward Capacity Auction supplemented by Reconfiguration Auctions occurring less than three years before the delivery period. ${ }^{234}$

ISO-NE experienced declining reliability in New England, which it attributed to the complexity of the ISO-NE Forward Capacity Market. ISO-NE found that capacity payments were poorly linked to resource performance — "resources [were] paid for simply existing, rather than for actually performing," which left "little incentive for resource owners to make investments" to ensure that resources are ready to perform. ${ }^{235}$ This led to the increased failure of resource owners to secure their fuel supply and, because of the increased shift to natural gas, increased vulnerability to interruptions in natural gas supply. The ISO-NE also observed that it is problematic to have penalties capped "such that there [could] be no net loss on [Forward Capacity Market] obligations, no matter how poorly the resource perform[ed]."236 The ISO-NE also concluded that because resources with lower going-forward costs and relatively poor performance would clear the Forward Capacity Auction before the more reliable resources with a higher going-forward cost, there was a structural bias toward the clearing of less reliable resources. These problems led the ISO-NE to propose a pay-forperformance model to FERC. ${ }^{237}$

For an overview, see Charles River Associates, Study, supra note 218; Charles River Associates, Appendices, supra note 218.

US, FERC, Order on Rehearing and Compliance (155 FERC 9 61,157) (10 May 2016) at para 4.

US, FERC, Motion to Intervene and Comments of the Market Monitoring Unit on Proposed Tariff Revisions Regarding Capacity Exports From Certain Localities (FERC Doc No ER17-446-000) (21 December 2016) at 2.

US, FERC, Attachment I-1a Transmittal Letter on Behalf of the ISO (FERC Doc No ER14-1050-000) (17 January 2014) at 3.

Ibid at 4.

Ibid at 2 . 
After a lengthy proceeding, with changes meant to remedy the problems proposed by both ISO-NE and the New England Power Pool Participants Committee (NEPOOL), FERC reached the conclusion that ISO-NE's Forward Capacity Market payment design was indeed unjust and unreasonable, that neither ISO-NE's nor NEPOOL's solutions, standing alone, had been shown to be just and reasonable, and that FERC would combine aspects of both proposals, as modified by FERC, to create a solution. ${ }^{238}$ FERC found that it was a flaw of the ISO-NE's then-existing capacity market that a resource's operational characteristics do not impact its capacity revenues — that "the market design [did] not consider a resource's operational characteristics in determining that resource's value." ${ }^{239}$ FERC implemented a two-settlement Forward Capacity Market model whereby a capacity resource's total revenue is comprised of a Capacity Base Payment and a Capacity Performance Payment, the former being determined by the Forward Capacity Auction clearing price and the latter being determined by the resource's performance during Capacity Scarcity Conditions. FERC created an exemption from the Capacity Performance Payments for resources on the export side of an intra-zonal transmission constraint during a Capacity Scarcity Condition. FERC also adopted increased Reserve Constraint Penalty Factors and a number of other changes. ${ }^{240}$

PJM experienced a similar problem. PJM found that "in recent years [its] capacity construct has failed to fully ensure that capacity resources will perform when called upon, in the event of an emergency." 241 PJM argued that this "construct has threatened reliability, while requiring consumers to pay for capacity that might lack a sufficient (and commensurate) reliability benefit." 242 Accordingly, PJM proposed, and in May 2016, FERC approved, enhanced capacity resource performance requirements, a Non-Performance Charge mechanism, more stringent consequences for failing to deliver energy or reserves during emergency conditions, and various other changes to its capacity market. FERC noted that PJM had "presented compelling evidence in this proceeding that capacity resource performance has deteriorated significantly since PJM implemented its Reliability Pricing Model (RPM) to ensure resource adequacy in the PJM region." 243 Several parties to that proceeding argued that the Capacity Performance reforms were "too costly for the benefits produced," but FERC found that PJM had "provided evidence that its pre-existing capacity market rules, and the penalties for non-performance, were inadequate to ensure that resources will perform during the most critical periods of the delivery year." ${ }^{244}$

FERC's changes to the ISO-NE and PJM capacity markets to incorporate performancebased incentives into the market design are not without controversy, however. Both have been appealed to the courts, and one key element of contention is the impact that a performance-based incentive structure would have on renewable resources.

FERC's decisions in the ISO-NE case were appealed to the United States Court of Appeals for the District of Columbia Circuit (DC Circuit), the federal district court which

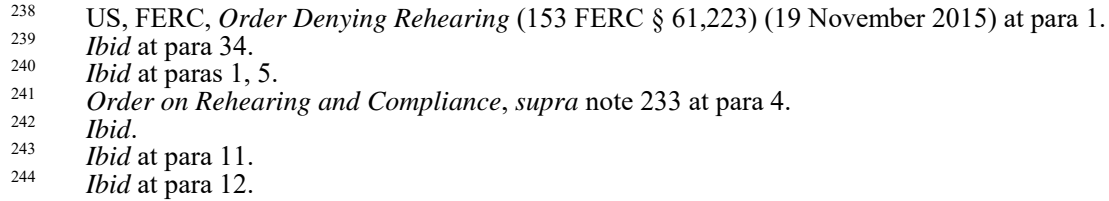


hears the most appeals of FERC cases, by the New England Power Generators Association, Inc. (NEPGA). NEPGA argues that FERC's decision was arbitrary and capricious for a number of reasons, including its failure to fully consider and address the impact of its increase to the Shortage Price Adders on the Peak Energy Rebate that generators must pay. ${ }^{245}$ NEPGA makes clear in its brief that it expects the pay for performance measures to have a very detrimental impact upon generators. The case is still pending at the time of writing and oral argument has not yet been scheduled.

The PJM case has also been appealed to the DC Circuit by a powerful coalition of environmental groups including the National Resources Defense Council, Sierra Club, and the Union of Concerned Scientists, trade associations such as the American Public Power Association, the National Rural Electric Cooperatives Association, Public Power Association of New Jersey, American Municipal Power Inc., and Advanced Energy Management Alliance, as well as the New Jersey Board of Public Utilities (the New Jersey state regulator). They argue that FERC's orders were arbitrary and capricious for a number of reasons, including: (1) it will impose substantial costs with no net benefits and FERC failed to properly evaluate the costs and benefits; (2) it will be unduly discriminatory against renewable resources and demand resources and it unduly discriminates against seasonal resources; and (3) the non-performance charge design fails to achieve effective penalties. ${ }^{246}$ Oral argument on the case was heard by the Court on 14 February 2017, and the Court has yet to render an opinion as of the time of writing. Once it does, the case may be further appealed to the US Supreme Court.

These cases illustrate the problem that capacity markets that do not provide incentives or penalties for performance can result in a decrease in reliability, due to the tendency for the market to select the cheapest generators, which are often the least reliable. The cases also underscore the tension between encouraging reliability and encouraging renewables.

US capacity markets have encountered another unanticipated problem related to the interconnection of regions. Because of the interties between RTOs, an attempt to solve capacity problems in one RTO can cause problems to arise in another. In a further attempt to address the capacity problems in ISO-NE, in October 2016, FERC approved a rule change to allow external capacity that would qualify for ISO-NE's Forward Capacity Auction to also bid into ISO-NE's shorter-term Reconfiguration Auctions. This resulted in a resource in the NYISO's Zone G, an import-constrained zone, qualifying to sell its capacity into ISO-NE, the first time resources in import-constrained zones in the NYISO had an incentive to export to New England. ${ }^{247}$ The NYISO's existing rules would have treated a generator exporting capacity to neighbouring control areas as if it does not exist, and would have required complete replacement of that capacity in the constrained area. Because the generator in the constrained area would still provide some benefits to the constrained area, however, it would not actually need to be replaced in its entirety, and doing so would produce capacity prices (filed 7 July 2016). Petitioners (filed 10 January 2017).

247 New York Independent System Operator Inc, FERC Doc No ER17-446-000, Motion to Intervene and Comments of the Market Monitoring Unit on Proposed Tariff Revisions Regarding Capacity Exports from Certain Localities, Potomac Economics (21 December 2016) at 2. 
that are not reflective of the marginal reliability value of capacity in the local area. Because the change in ISO-NE's rules accelerated this situation more quickly than the NYISO had anticipated, it had to propose temporary rules on an expedited basis to get a rule in place in time for the capacity auction run in early 2017 for the 2017-2018 Capability Year. The ISONE proposed a Locality Exchange Factor that would reflect the percentage of the exporting capacity resource's capacity that would need to be replaced. FERC accepted the Locality Exchange Factor over the objections of competitive generators that it would double-count capacity (though it rejected the proposed one-year transitional structure of it) and supported the ISO-NE's reasoning. Rehearing of the case is pending at the time of writing. ${ }^{248}$

\section{LeSSONS LeARNED AND APPLiCATION TO AlbERTA}

Introducing a capacity market along the lines proposed by the AESO is a radical departure from what has been defined as Alberta's liberalized energy market - namely, its energyonly character and reliance on energy market price signals to stimulate the construction of new capacity. ${ }^{249}$

The primary lesson Alberta can learn from the German capacity regime at this stage is that there are alternatives to a market-wide capacity mechanism. Here we focus on the lessons from Great Britain and the US - particularly the former, since aspects of Alberta's proposals are quite similar to the British model.

When Great Britain's capacity market was introduced, the government took the view that a significant amount of new, large-scale CCGT capacity (and perhaps also some simple cycle plants) was needed to replace Great Britain's rapidly shrinking fleet of coal-fired power stations and insufficiently flexible older gas-fired plants, and to back up intermittent renewable generation. In the years leading up to the launch of EMR, developers had built up a large bank of approved CCGT projects - well over $10 \mathrm{GW}$ of potential new generation - but had taken no steps to construct them. This was because UK wholesale gas prices were relatively high in comparison with wholesale power prices, and it was assumed that things would stay this way. ${ }^{250}$

The capacity market was designed to provide developers with the money needed for new large-scale gas-fired plants. Judged by this criterion, it has so far failed. After three rounds of auctions, only one genuinely new large-scale gas-fired plant has been awarded a capacity agreement - and that agreement was terminated after the failure of financial arrangements

248 See Order on Rehearing and Compliance, supra note 233; US, FERC, Order Accepting Subject to Condition in Part and Rejecting in Part Tariff Revisions (158 FERC 91,064) (27 January 2017) at para 35 .

249 For a bracing analysis of the weakness of capacity markets (or at least those forms of capacity-related market intervention that involve all or most of the energy market as well), see Connect Energy Economics, "Upgrading the Internal Market: The Power Market 2.0" (29 June 2016), online: BMWi $<$ https://www.bmwi.de/Redaktion/EN/Publikationen/upgrading-internal-market.html $>$ ["BMWi Study"]. Details of consents for new generation projects can be found at UK Government, Department for Business, Energy \& Industrial Strategy, "Decisions on Applications Since 2005," online: <https://it portal.beis.gov.uk/EIP/pages/recent.htm $>$. For gas and power prices, see UK Government, Department of Energy \& Climate Change, DECC Fossil Fuel Price Projections (October 2012) at 6, online: $<$ https://www.gov.uk/government/uploads/system/uploads/attachment_data/file/65698/6658-decc-fossilfuel-price-projections.pdf>; Ofgem, "Day-Ahead Baseload Contracts," supra note 111. 
that would meet interim delivery milestones required under the Capacity Market Rules. ${ }^{251}$ Clearing prices have been too low to support a CCGT project, unless it benefits from a longterm PPA or tolling agreement. Unfortunately, the market has little appetite for such arrangements at present.

The regime has stimulated some new build projects, but these have invariably been smallscale modular peaking plants exploiting a loophole in the transmission charging regime providing an additional subsidized revenue stream that allowed them to make capacity market bids below what developers of larger-scale plants could offer.

Many of these small-scale plants are diesel-fired, meaning that the capacity market increases, rather than reduces, the emissions footprint of the overall generating fleet. It was perfectly clear from the results of the first auction, held in 2014, that the regime was not working as intended. Nevertheless, the government held further auctions in the following two years without making material changes to the regime - and experienced more or less exactly the same results. ${ }^{252}$

How relevant is this to Alberta? Some factors were specific to Britain's transmission charging regime that enhanced the ability of small-scale plants to bid into the capacity market auction at much lower prices than larger new-build projects, ${ }^{253}$ but that does not diminish the broad comparison to Alberta for three reasons. First, aside from the advantage related to transmission charging, the kind of result seen in Great Britain is, to some degree, inevitable in any case when the small-scale plants have lower fixed costs and higher variable costs than CCGT, and therefore require fewer hours of operation each year to be economically viable. ${ }^{254}$ Second, introducing a significant change with the potential to distort the energy market, like a capacity market across almost the whole market, is likely to highlight and magnify other weaknesses in the regulatory architecture. ${ }^{255}$ Third, applying a capacity market regime across

See Tom Grimwood, "Trafford Power Station Reneges on Capacity Agreement," UtilityWeek (20 December 2016), online: <utilityweek.co.uk/news/trafford-power-station-reneges-on-capacity-agree ment/1291592\#.WOP 7E0-QzL8>.

Adam Brown, "Close But No Cigar? What's Different About the T-4 Capacity Market Auction Results of 2016?" (9 December 2016), Dentons Global Energy Blog (blog), online: <www.globalenergyblog. com/close-but-no-cigar-whats-different-about-the-t-4-capacity-market-auction-results-of-2016>

Essentially, a small-scale plant is able to connect to the distribution network and is treated as "negative demand," rather than "generation" for the purposes of the transmission charging regime. It pays no transmission charges, but by ensuring that it generates during the three half-hourly periods of peak demand each year on the basis of which transmission charges are calculated, it receives (directly or indirectly) a substantial payment from National Grid. This part of the charging regime was originally designed to reward distributed generation for reducing the pressure on the transmission system at times of peak demand, but Ofgem has calculated that as the market has developed, distributed generators are being substantially over-rewarded for any benefit of this kind that they bring: see Ofgem, "Embedded Benefits: Impact Assessment and Decision on Industry Proposals (CMP264 and CMP265) to Change Electricity Transmission Charging Arrangements for Embedded Generators" (22 June 2017), online: $<$ https://www.ofgem.gov.uk/publications-and-updates/embedded-benefits-impact-assessment-anddecision-industry-proposals-cmp264-and-cmp265-change-electricity-transmission-chargingarrangements-embedded-generators $>$. "BMWi Study," supra note 249 at 10.

In Great Britain, the issue noted above with transmission charges had been considered on a number of previous occasions, and was to some extent recognized as anomalous, but it was not found to create serious difficulties until the Capacity Market came into effect and changed the context in which it operated. See the linked documents on Ofgem, "Embedded Benefits: Consultation on CMP264 and CMP265 Minded to Decision and Draft Impact Assessment" (1 March 2017), online: <https://www. ofgem.gov.uk/publications-and-updates/embedded-benefits-consultation-cmp264-and-cmp265-mindeddecision-and-draft-impact-assessment>. 
the whole market inevitably favours incumbent players, and while it may produce lower per $\mathrm{kW}$ prices, it will tend to be more expensive overall than a more targeted approach. ${ }^{256}$

As a result of Great Britain's capacity market auctions to date, large amounts of existing generating capacity, including coal-fired plants, will receive capacity payments to supplement their power sales revenues from October 2018. These are payments just for being available to generate - in other words, for doing what they would, in all probability, have been doing in any event. The availability of this extra revenue may help to depress wholesale market prices and therefore increase the cost of CFD subsidies. At the same time, businesses that set out to provide genuine demand-side response (that is not just backup, behind-thefence generation for industrial customers) complain, sometimes with a degree of justification, that the organization and regulation of the capacity market has a built-in tendency to favour existing generation. One such organization, Tempus Energy, has even challenged the European Commission's decision to grant clearance to the regime under the EU's state aid rules. $^{257}$

The advice to authorities in Alberta from the perspective of Great Britain and US experience is as follows.

- Capacity mechanisms have multiple effects on the market and can magnify existing regulatory problems. In designing capacity mechanisms, great care must be taken to avoid unintended consequences.

- The underlying rationale of capacity mechanisms runs against the grain of an energy-only market where peak price spikes should spur investment. Capacity mechanisms aim to flatten the peaks.

- $\quad$ Every market is different. Alberta's energy market has a number of features that are not paralleled in the markets of other jurisdictions that have adopted capacity mechanisms. $^{258}$

In Great Britain, the Capacity Market was originally scheduled to deliver for the first time in 2018 (when those who were successful in the four year ahead auction of 2014 would be called upon). The National Grid had some concerns about supply margins and developed a process of tendering for a Contingency Balancing Reserve (CBR) to ensure that additional capacity was available over the winter periods before 2018-2019. On the generation side, only plants that would otherwise not be in the market (for example, because of being closed or mothballed) were eligible for the CBR. The government became concerned at the level of payments being made to CBR participants and decided that it would be better to have no CBR for 2017-2018 but instead to have an early Capacity Market auction, which took place in January 2017. The result was that $54.43 \mathrm{GW}$ of capacity was procured, at $£ 6.95 \mathrm{~kW} /$ year, suggesting total costs to bill payers of around $£ 378$ million. Over 90 percent of this capacity would have been in the market anyway. For comparison, in the most recent previous CBR auction for which figures are available (for 2015-2016), National Grid spent just over $£ 31$ million on procuring, testing, and utilizing less than 3 GW of CBR capacity: arguably rather better value. It may be argued that a measure like the CBR is not the best way to stimulate the development of new large-scale capacity, but if market-wide measures in general are better from that point of view, the Great Britain version is still, so far, not an ideal model. See Adam Brown, "UK 'Early' Capacity Market Auction Produces Lowest Prices Yet” (6 February 2017), Dentons Global Energy Blog (blog), online: <www.globalenergyblog.com/uk-early-capacitymarket-auction-produces-cheapest-prices-yet $>$. See also the linked documents on National Grid, “Contingency Balancing Reserve," online: <www2.nationalgrid.com/UK/Services/Balancing-services/ System-security/Contingency-Balancing-Reserve/>. More commentary on Great Britain's Capacity Market can be found on Dentons Global Energy Blog, online: $<$ www.globalenergyblog.com/?s=capacity+market $>$. 
- It is reasonable to start from the premise that a capacity mechanism should be "technologically neutral," and that all that matters is procuring security of supply at lowest cost. But if, in fact, what you want is to stimulate a particular kind of project (such as a CCGT plant, DSR, or storage), neutrality may not be the right starting point (or it may be false to claim it as one).

- In a market-wide mechanism that makes no attempt to discriminate between different kinds of capacity, large existing generators have a significant built-in advantage. To ensure that other kinds of projects have a fair chance of competing with them, the rules need to recognize that.

- $\quad$ Capacity markets that incentivize only the cheapest capacity without reference to whether the asset actually performs when called upon will harm reliability by giving capacity owners an incentive to keep their assets as cheap as possible and not invest in measures to make those assets more reliable. Performance measures may solve the problem, but potentially at the cost of creating barriers for renewable capacity to enter the market.

- $\quad$ Particular difficulties arise if capacity located in other jurisdictions is allowed to participate in a capacity market, or where the same capacity may be contracted to two different markets. Where two capacity markets are interconnected, changes to the rules of one market may have unintended consequences for the interconnected capacity market.

- Capacity mechanisms are fertile ground for lawyers. The US capacity markets have given rise to extensive litigation and regulatory proceedings, as exemplified by some of the cases referred to above. In their much shorter life, the originally 143 pages of Great Britain Capacity Market Rules have so far grown by almost 70 percent, with over 80 rule changes being proposed each year. ${ }^{259}$

\section{Conclusions}

Alberta has set off down the path of electricity market reform. It is responding to the challenges of the energy trilemma with a CFD-based system of renewables support, initially, and a market-wide capacity mechanism. The REP is well on the way to its first auction. The capacity market is at an earlier stage of development. But already, there is probably no going back to the apparently simple certainties of the energy-only market.

There are three ways in which Alberta is well-placed to benefit from not being among the first jurisdictions to initiate a large-scale program of renewable electricity generation subsidy or a capacity market. 
- By starting to deploy renewables on a large scale now, Alberta will benefit from the reductions in wind and solar technology costs that have been driven by renewables programs elsewhere.

- Experience from other jurisdictions shows the advantages of a CFD-based scheme for renewables. Both Great Britain and Germany provide good models for developing such a regime. For capacity markets, there are both positive and negative lessons to learn from Great Britain and the US.

- Again, by virtue of timing, Alberta is in a better position to design a regime that is future-proofed to make the most of new storage and other technologies that are starting to address the problems of the trilemma.

The REP design shows that Alberta has already learned key lessons from initiatives in other jurisdictions. Programs must reflect different circumstances. They must evolve when rules do not produce the desired outcome, as happened in the Great Britain Capacity Market. Likewise, Alberta should be prepared to learn from its own experience. 
[this page is intentionally blank] 